\title{
Oiling the Brain: A Review of Randomized Controlled Trials of Omega-3 Fatty Acids in Psychopathology across the Lifespan
}

\section{Natalie Sinn *, Catherine Milte and Peter R. C. Howe}

Nutritional Physiology Research Centre, Sansom Institute for Health Research, University of South Australia, Frome Road, Adelaide 5000, Australia; E-Mails: catherine.milte@unisa.edu.au (C.M.); peter.howe@unisa.edu.au (P.H.)

* Author to whom correspondence should be addressed; E-Mail: natalie.sinn@unisa.edu.au.

Received: 3 December 2009 / Accepted: 3 February 2010 / Published: 9 February 2010

\begin{abstract}
Around one in four people suffer from mental illness at some stage in their lifetime. There is increasing awareness of the importance of nutrition, particularly omega-3 polyunsaturated fatty acids (n-3 PUFA), for optimal brain development and function. Hence in recent decades, researchers have explored effects of n-3 PUFA on mental health problems over the lifespan, from developmental disorders in childhood, to depression, aggression, and schizophrenia in adulthood, and cognitive decline, dementia and Alzheimer's disease in late adulthood. This review provides an updated overview of the published and the registered clinical trials that investigate effects of n-3 PUFA supplementation on mental health and behavior, highlighting methodological differences and issues.
\end{abstract}

Keywords: omega-3 polyunsaturated fatty acids; mental health; attention deficit hyperactivity disorder; autism; aggression; depression; dementia

\section{Introduction}

Mental health is described as "a state of well-being in which every individual realizes his or her own potential, can cope with the normal stresses of life, can work productively and fruitfully, and is able to make a contribution to her or his community" [1]. About 450 million people worldwide do not enjoy this state of wellbeing, and it is estimated that one in four people will suffer from mental illness at some stage in their lifetime, causing enormous suffering, personal, social and financial burden, as 
well as associated physical illness [2]. Identification of preventable risk factors and effective treatments therefore constitutes an international priority.

Nutrition has an important role in mental health as the brain relies on both macro- and micronutrients for development and functioning [3-6]. In particular, suboptimal levels of omega-3 polyunsaturated fatty acids (n-3 PUFA) are emerging as a potentially modifiable risk factor for mental illness. Since their discovery in the 1970s as key components of brain tissue [7], long-chain n-3 PUFA have been postulated to serve critical roles in brain development, and function and a lack of these fatty acids has been implicated in a number of mental health conditions over the lifespan, from developmental disorders and mental retardation in childhood, to depression, bipolar disorder, schizophrenia and borderline personality disorder, stress, hostility and aggression in adulthood, and cognitive decline, dementia and Alzheimer's disease in late adulthood [8].

Although the etiology of these disorders is clearly multifactorial and subject to individual variation, the number of clinical trials addressing suboptimal n-3 PUFA levels as a possible underlying biological contributor to associated symptoms, and importantly symptoms that often co-occur and overlap between these disorders, is steadily growing. Following an overview of n-3 PUFA, we will provide a review of randomized controlled trials [8], and an update of recent trials located via the World Health Organization's International Clinical Trials Registry Platform Search Portal [9], including preliminary results from our own recent studies, focusing on the role of n-3 PUFA in alleviating symptoms of psychopathology from childhood throughout adulthood. Trial identification numbers of registered trials not included in the original review were searched on PubMed to check if they had been published. Published and registered trials are summarized in Tables 1 and 2, respectively.

\section{Omega-3 PUFA}

\subsection{Overview}

The omega-6 (n-6) and n-3 families of PUFA have numerous biological roles in cellular structure and function. Alpha linolenic acid (ALA; 18:3n-3), parent n-3 PUFA, and linoleic acid (LA; 18:2n-6), parent n-6 PUFA, cannot be synthesized by humans and must be provided via the diet. They are therefore termed essential fatty acids (EFA). Humans can obtain ALA in their diet via plant sources. EFA have 18 carbon atoms with double carbon bonds. These chains undergo further processes of elongation and de-saturation (insertion of additional double bonds) to form highly unsaturated long chain (LC) PUFA. Our bodies can perform these conversions, although not always very efficiently. Long chain (LC) derivatives of ALA, eicosapentaenoic acid (EPA) and docosahexaenoic acid (DHA), are made by phytoplankton and transferred via the food-chain to marine organisms, particularly coldwater fish and marine animals. Therefore, humans can also obtain these elongated n-3 PUFA directly via algal or fish sources.

Structurally, PUFA are key components of phospholipids, comprising cellular and intracellular membranes. They govern growth and vitality through oxidation (metabolism of food to produce energy required for cellular processes), chemical activities and transportation. As well as constructing membranes and generating and propagating electrical impulses, LC-PUFA are required for synthesis of 
eicosanoids, important signaling hormones with numerous complex functions. Those derived from n-3 LC-PUFA are generally anti-inflammatory, anti-thrombotic and vasodilatory, balancing and counteracting pro-inflammatory, vasoconstrictor actions of eicosanoids derived from n-6 LC PUFA [10]. The cardiovascular benefits of n-3 PUFA [11] are largely attributed to these eicosanoid properties, and they may also have important roles in brain function.

\subsection{Omega-3 PUFA and the Brain}

Lipids constitute approximately sixty percent of the dry weight of the brain. DHA and AA are the most highly concentrated PUFA in neural phospholipids, including subcellular membranes [12-14]. Although the circulation contains at least 10 times more n-6 than n-3 PUFA, DHA predominates in the retina, brain and nervous system [14]. Furthermore, DHA is particularly concentrated at neural synapses [15-19].

Importantly, DHA levels in neural membranes vary according to dietary oil intake $[4,19,20]$ and there is evidence that low PUFA and high cholesterol levels reduce phospholipid fluidity [19,20]. Animal studies and human infant autopsies have also shown that when insufficient n-3 PUFA are available during early neural development, there is a decrease in the DHA content of the brain. Furthermore, increased n- 6 to n-3 PUFA ratios can also alter the fatty acid composition of neural membranes [21].

Various reviews have outlined biological mechanisms for n-3 PUFA in brain function [22-24]. In particular, and in line with a longstanding focus on the role of neurotransmitters such as dopamine and serotonin in mental illness, research has focused on associations between PUFA and central nervous system activity [25]. Evidence points to the role of eicosanoids in healthy brain functioning, and phospholipid membranes in neural cell signaling [12,19,26,27]. Levels of n-3 PUFA have been associated with monoaminergic neurotransmitter levels [27-30]. n-3 deficiency has also been found, in animal studies, to reduce levels of phosphatidylserine (PS) in the brain, which is thought to play an important function in neural signaling activities [12]. In alcoholics, DHA deficiency has predicted reduced 5-hydroxyindoleacetic acid (5-HIAA) concentrations in cerebrospinal fluid, an indicator of low serotonin turnover rate in the frontal cortex [31].

Studies have further indicated that n-3 PUFA may affect receptor properties or activation of signal transduction by receptors [30]. Electrical impulse conduction is dependent on the exchange of ions through the cell membrane, which relies on the fluidity and physiological structure of cell membranes. Furthermore, there are indications that PUFA are involved in the synthesis and activities of brain peptides [19], which are involved in modulating the activities of neurotransmitters [32]. n-3 PUFA are also thought to influence gene expression of a range of enzymes required for important neural functions including synaptic transduction, ion channel formation, energy metabolism and formulation of proteins vital for brain development and function [22].

Regular delivery of oxygen and nutrients via the blood is also critical for optimal brain function, and psychopathology is associated with both reduced cerebral blood flow and transportation of glucose, the brain's primary energy source, to brain regions as required. In this regard, n-3 PUFA are associated with production of nitric oxide [33], as well as anti-inflammatory and vasodilatory eicosanoids (notably $\mathrm{PGI}_{2}$ ), and are known to assist in endothelial-dependent vasodilation [10]. They 
have also been associated with substantially increased transport of glucose across the blood-brain barrier [34,35]. Therefore, it is also possible that their primary influence on brain function includes improved cerebral blood flow and blood-brain barrier integrity [36]. This notion is supported by the high co-morbidity between cardiovascular disease and psychopathology, indicative of a common underlying vascular pathology that may be mediated by lifestyle factors such as suboptimal levels of $\mathrm{n}$ 3 PUFA [37].

A review of controlled animal studies [30] concluded that there is sufficient evidence of a role for $n-$ 3 PUFA in improving learning and behavior. A large body of research has investigated n-3 PUFA in infant development, which is also reviewed elsewhere [38]. The present review will focus on mental health problems in childhood through to late adulthood.

\section{PUFA and Mental Illness}

PUFA deficiencies have been reported in people with a range of psychiatric problems [22-24,39-41], including developmental disorders such as attention deficit hyperactivity disorder (ADHD), depression, bipolar disorder, stress, aggression, hostility and criminality, and dementia. A small but growing body of clinical research trials has been conducted with variable outcomes. These will be reviewed here, and are summarized in Table 1.

Table 1. Double-blind randomized placebo-controlled trials of omega-3 fatty acids in mental illness.

\begin{tabular}{|c|c|c|c|c|c|}
\hline Authors & Participants & Daily dosage & $\begin{array}{l}\text { Length of } \\
\text { trial }\end{array}$ & Measures & Outcomes* \\
\hline $\begin{array}{l}\text { Voigt et al. } \\
\text { (2001) [53] }\end{array}$ & $\begin{array}{l}N=54 ; 6-12 \text { year old } \\
\text { (78\% boys); idiopathic } \\
\text { ADHD diagnosis; were } \\
\text { being treated successfully } \\
\text { with medication }\end{array}$ & $\begin{array}{l}345 \text { mg DHA } \\
\text { (algae-derived) } \\
\text { or undefined } \\
\text { placebo }\end{array}$ & 16 weeks & $\begin{array}{l}\text { CPRS; CBC; } \\
\text { TOVA; CCT }\end{array}$ & $\begin{array}{l}\text { Treatment }=\text { placebo on all } \\
\text { measures }\end{array}$ \\
\hline $\begin{array}{l}\text { Stevens et } \\
\text { al. (2003) } \\
{[59]}\end{array}$ & $\begin{array}{l}N=50 ; 6-13 \text { year old } \\
\text { (78\% boys); ADHD } \\
\text { diagnosis; high FADS; } \\
\text { some on medication } \\
\text { (equally allocated to } \\
\text { conditions) }\end{array}$ & $\begin{array}{l}96 \mathrm{mg} \text { GLA, } 40 \\
\mathrm{mg} \text { AA, } 80 \mathrm{mg} \\
\text { EPA, } 480 \mathrm{mg} \\
\text { DHA, } 24 \mathrm{mg} \\
\text { Vit E or olive } \\
\text { oil placebo }\end{array}$ & 16 weeks & $\begin{array}{l}\text { DBD; ASQ; } \\
\text { CPT; } \\
\text { WJPEB-R; } \\
\text { FADS }\end{array}$ & $\begin{array}{l}\text { Treatment > placebo: } \\
\text { DBD-Conduct (parents); } \\
\text { DBD-Attention (teachers). } \\
\text { Other } 14 \text { outcome } \\
\text { measures non-significant }\end{array}$ \\
\hline $\begin{array}{l}\text { Hirayama et } \\
\text { al. (2004) } \\
{[55]}\end{array}$ & $\begin{array}{l}N=40 ; 6-12 \text { year old } \\
\text { ( } 80 \% \text { boys); ADHD } \\
\text { diagnosis; } 15 \% \text { medicated; } \\
82 \% \text { comorbid conditions }\end{array}$ & $\begin{array}{l}100 \text { mg EPA, } \\
514 \text { mg DHA } \\
\text { or olive oil } \\
\text { placebo } \\
\text { (supplied in } \\
\text { soymilk \& } \\
\text { bread) }\end{array}$ & 8 weeks & $\begin{array}{l}\text { ADHD } \\
\text { DSM-IV; } \\
\text { DTVP; STM; } \\
\text { CPT; Other }\end{array}$ & $\begin{array}{l}\text { Treatment }=\text { placebo on all } \\
\text { measures (except that } \\
\text { placebo }>\text { treatment on } \\
\text { CPT and STM) }\end{array}$ \\
\hline
\end{tabular}


Table 1. Cont.

\begin{tabular}{|c|c|c|c|c|c|}
\hline $\begin{array}{l}\text { Richardson } \\
\text { \& Puri } \\
(2002) \text { [58] }\end{array}$ & $\begin{array}{l}N=29 ; 8-12 \text { year old } \\
\text { (62\% boys); normal IQ; } \\
\text { low reading ability; above } \\
\text { average ADHD scores on } \\
\text { Conners' Index; no } \\
\text { participants in treatment } \\
\text { for ADHD }\end{array}$ & $\begin{array}{l}864 \mathrm{mg} \text { LA, } 42 \\
\mathrm{mg} \text { AA, } 96 \mathrm{mg} \\
\text { ALA, } 186 \mathrm{mg} \\
\text { EPA, } 480 \mathrm{mg} \\
\text { DHA, } 60 \mathrm{i} \mu \mathrm{Vit} \\
\text { E or olive oil } \\
\text { placebo }\end{array}$ & 12 weeks & CPRS & $\begin{array}{l}\text { Treatment > placebo: } \\
\text { CPRS; Cognitive } \\
\text { problems/inattention; } \\
\text { Anxious/shy; Conners, } \\
\text { global index; DSM } \\
\text { inattention; DSM } \\
\text { hyperactive/impulsive; } \\
\text { Conners' ADHD Index }\end{array}$ \\
\hline $\begin{array}{l}\text { Richardson } \\
\& \\
\text { Montgomery } \\
\text { (2005) [60] }\end{array}$ & $\begin{array}{l}N=117 ; 5-12 \text { year old } \\
(77 \% \text { boys); } \\
\text { Developmental } \\
\text { Coordination Disorder, } 1 / 3 \\
\text { with ADHD symptoms in } \\
\text { clinical range, not in } \\
\text { treatment; IQ }>70 ;\end{array}$ & $\begin{array}{l}60 \text { mg AA, } 10 \\
\text { mg GLA, } 558 \\
\text { mg EPA, } 174 \\
\text { mg DHA, } 9.6 \\
\text { mg Vit E or } \\
\text { olive oil } \\
\text { placebo }\end{array}$ & $\begin{array}{l}12 \text { weeks } \\
\text { active } v s \text {. } \\
\text { placebo; } \\
\text { one-way } \\
\text { crossover } \\
\text { to active } \\
\text { treatment } \\
\text { for } 12 \\
\text { weeks }\end{array}$ & $\begin{array}{l}\text { MABC; } \\
\text { WORD; } \\
\text { CTRS }\end{array}$ & $\begin{array}{l}\text { Treatment > placebo: } \\
\text { WORD; CTRS } \\
\text { Oppositional behaviour; } \\
\text { Cognitive } \\
\text { problems/inattention; } \\
\text { Hyperactivity; } \\
\text { Anxious/shy; } \\
\text { Perfectionism; Social } \\
\text { problems; Conners' index, } \\
\text { DSM-IV inattention, } \\
\text { hyperactive/impulsive } \\
\text { Treatment = placebo: } \\
\text { MABC }\end{array}$ \\
\hline $\begin{array}{l}\text { Sinn et al. } \\
(2007 ; 2008) \\
{[61,62]}\end{array}$ & $\begin{array}{l}N=132 \text { (questionnaire } \\
\text { data available for 104); } 7- \\
12 \text { year old ( } 74 \% \text { boys); } \\
\text { ADHD symptoms in } \\
\text { clinical range; } \\
\text { unmedicated }\end{array}$ & $\begin{array}{l}60 \text { mg AA, } 10 \\
\text { mg GLA, } 558 \\
\text { mg EPA, } 174 \\
\text { mg DHA, } 9.6 \\
\text { mg Vit E, or } \\
\text { palm oil } \\
\text { placebo }\end{array}$ & $\begin{array}{l}15 \text { weeks } \\
\text { active } v s \text {. } \\
\text { placebo; } \\
\text { one-way } \\
\text { crossover } \\
\text { to active } \\
\text { treatment } \\
\text { for } 15 \\
\text { weeks }\end{array}$ & $\begin{array}{l}\text { CPRS, CTRS } \\
\text { Vocabulary, } \\
\text { subtests from } \\
\text { WISC-III \& } \\
\text { TEA-ch, } \\
\text { Stroop }\end{array}$ & $\begin{array}{l}\text { Treatment }>\text { placebo } \\
\text { CPRS: Cognitive } \\
\text { problems/inattention; } \\
\text { Hyperactivity; ADHD } \\
\text { Index; Restless/Impulsive; } \\
\text { DSM-IV } \\
\text { Hyperactive/Impulsive; } \\
\text { Oppositional. Treatment = } \\
\text { placebo on other subscales } \\
\text { and CTRS. } \\
\text { Treatment }>\text { placebo on } \\
\text { Creature Counting \& } \\
\text { vocabulary. Treatment = } \\
\text { placebo on other cognitive } \\
\text { tests }\end{array}$ \\
\hline
\end{tabular}


Table 1. Cont.

\begin{tabular}{|c|c|c|c|c|c|}
\hline $\begin{array}{l}\text { Johnson et } \\
\text { al. }(2008) \\
{[64]}\end{array}$ & $\begin{array}{l}N=75,8-18 \text { year old } \\
\text { children with diagnosed } \\
\text { ADHD, unmedicated } \\
\text { (85\% males) }\end{array}$ & $\begin{array}{l}60 \text { mg AA, } 10 \\
\text { mg GLA, } 558 \\
\text { mg EPA, } 174 \\
\text { mg DHA, } 9.6 \\
\text { mg Vit E or } \\
\text { olive oil } \\
\text { placebo }\end{array}$ & $\begin{array}{l}3 \text { months } \\
\text { active } v s \text {. } \\
\text { placebo; } \\
\text { one-way } \\
\text { crossover } \\
\text { to active } \\
\text { treatment } \\
\text { for } 3 \\
\text { months }\end{array}$ & $\begin{array}{l}\text { Investigator- } \\
\text { rated ADHD } \\
\text { Rating Scale- } \\
\text { IV; CGI }\end{array}$ & $\begin{array}{l}\text { Treatment }=\text { placebo } \\
\text { overall } \\
\text { Treatment }>\text { placebo in } \\
\text { subgroups with inattentive } \\
\text { subtype \& comorbid } \\
\text { neurodevelopmental } \\
\text { disorders }\end{array}$ \\
\hline $\begin{array}{l}\text { Milte et al. } \\
\text { (in } \\
\text { preparation) } \\
{[65]}\end{array}$ & $\begin{array}{l}N=54 \text { ( } 45 \text { with bloods), } \\
7-12 \text { year old ( } 79 \% \text { male) } \\
\text { with ADHD/ADHD } \\
\text { symptoms ( } 50 \% \\
\text { diagnosed) } \\
\text { ACTRN012607000332426 }\end{array}$ & $\begin{array}{l}1 \mathrm{~g} \text { EPA-rich } \\
\text { oil, } 1 \mathrm{~g} \text { DHA } \\
\text { rich oil or } \\
\text { sunflower oil } \\
\text { placebo }\end{array}$ & $\begin{array}{l}3 \times 3 \\
\text { crossover } \\
\text { (4 months } \\
\text { on each } \\
\text { treatment) }\end{array}$ & $\begin{array}{l}\text { CPRS, } \\
\text { reading, } \\
\text { writing, } \\
\text { vocabulary, } \\
\text { TEA-ch }\end{array}$ & $\begin{array}{l}\text { Treatment = placebo in 12- } \\
\text { month crossover. } \\
\text { Over } 4 \text { months erythrocyte } \\
\text { DHA increases associated } \\
\text { with improvements on } \\
\text { CPRS - oppositional } \\
\text { behaviour, anxiety/shyness } \\
\text { - divided attention \& } \\
\text { reading. In subgroup with } \\
\text { learning difficulties (n }=16 \\
\text { with blood) also on CPRS } \\
\text { hyperactivity/impulsivity } \\
\text { and spelling. }\end{array}$ \\
\hline $\begin{array}{l}\text { Amminger } \\
\text { et al. }(2007) \\
{[80]}\end{array}$ & $\begin{array}{l}N=13(5-17 \text { years }) \text { with } \\
\text { Autistic Disorder }(81.9 \% \\
\text { male })\end{array}$ & $\begin{array}{l}1.5 \mathrm{~g} / \mathrm{d} \mathrm{n}-3 \\
\text { PUFA }(0.84 \mathrm{~g} \\
\text { EPA, } 0.7 \mathrm{~g} \\
\text { DHA), Vit E; } \\
\text { or coconut oil } \\
\text { placebo }\end{array}$ & $\begin{array}{l}6 \text { weeks } \\
\text { parallel } \\
\text { design }\end{array}$ & $\begin{array}{l}\text { Aberrant } \\
\text { Behavior } \\
\text { Checklist } \\
\text { (ABC) }\end{array}$ & $\begin{array}{l}\text { Treatment }>\text { placebo for } \\
\text { stereotypy \& hyperactivity } \\
\text { (trends with large effect } \\
\text { sizes) } \\
\text { Treatment = placebo on } 3 \\
\text { other subscales }\end{array}$ \\
\hline $\begin{array}{l}\text { Peet \& } \\
\text { Horrobin } \\
(2002) \\
{[103]}\end{array}$ & $\begin{array}{l}N=70(18-70 \text { years }), \\
\text { depressed }(>15 \text { on HDRS }), \\
\text { medicated }\end{array}$ & $\begin{array}{l}\text { Ethyl-EPA }-1 \text {, } \\
2 \text { or } 4 \mathrm{~g} / \text { day or } \\
\text { placebo }\end{array}$ & $\begin{array}{l}12 \text { week } \\
\text { parallel } \\
\text { design, } \\
\text { adjunctive } \\
\text { therapy }\end{array}$ & $\begin{array}{l}\text { HDRS, } \\
\text { MADRS, } \\
\text { BDI }\end{array}$ & $\begin{array}{l}\text { Treatment }>\text { placebo on all } \\
3 \text { rating scales with } 1 \mathrm{~g} / \text { day } \\
\text { EPA - strong effects for } \\
\text { core depressive symptoms. } \\
\text { Treatment = placebo on } 2 \mathrm{~g} \\
\text { and } 4 \mathrm{~g} / \text { day (non-significant } \\
\text { trends) }\end{array}$ \\
\hline $\begin{array}{l}\text { Nemets et } \\
\text { al. }(2002) \\
{[104]}\end{array}$ & $\begin{array}{l}N=20 \text { ( } 28-73 \text { years }) \\
\text { diagnosed major } \\
\text { depression disorder }(85 \% \\
\text { women) HDRS score }>18\end{array}$ & $\begin{array}{l}2 \mathrm{~g} \text { ethyl-EPA } \\
(96 \% \text { from fish } \\
\text { oil) or placebo, } \\
\text { Vit } \mathrm{E}\end{array}$ & $\begin{array}{l}4 \text { weeks } \\
\text { parallel } \\
\text { design, } \\
\text { adjunctive } \\
\text { therapy }\end{array}$ & HDRS & $\begin{array}{l}\text { Treatment }>\text { placebo at } \\
\text { weeks 2, } 3 \text { and } 4 \text { on HDRS } \\
\text { score and on core } \\
\text { depressive symptom } \\
\text { subscales. }\end{array}$ \\
\hline
\end{tabular}


Table 1. Cont.

\begin{tabular}{|c|c|c|c|c|c|}
\hline $\begin{array}{l}\text { Su et al. } \\
(2003)[106]\end{array}$ & $\begin{array}{l}N=22 \text { (18-60 years), } \\
\text { outpatients with major } \\
\text { depressive disorder; } \\
\text { HDRS score }>18, \\
\text { medicated }\end{array}$ & $\begin{array}{l}3.3 \mathrm{~g} / \text { day } \mathrm{n}-3 \\
\text { PUFA }(2.2 \mathrm{~g} \\
\text { DHA, } 1.1 \mathrm{~g} \\
\text { EPA) }\end{array}$ & $\begin{array}{l}8 \text { weeks } \\
\text { parallel } \\
\text { design, } \\
\text { adjunctive } \\
\text { therapy }\end{array}$ & HDRS & $\begin{array}{l}\text { Treatment }>\text { placebo on } \\
\text { HDRS }\end{array}$ \\
\hline $\begin{array}{l}\text { Marangell et } \\
\text { al. (2003) } \\
{[111]}\end{array}$ & $\begin{array}{l}N=35 \text { (18-65 years }), \\
\text { major depressive disorder } \\
\text { diagnosis; HDRS score }> \\
16(80 \% \text { female })\end{array}$ & $\begin{array}{l}2 \mathrm{~g} / \text { day DHA or } \\
\text { placebo }\end{array}$ & $\begin{array}{l}6 \text { weeks } \\
\text { parallel }\end{array}$ & $\begin{array}{l}\text { MADRS, } \\
\text { HDRS, } \\
\text { GAFS }\end{array}$ & $\begin{array}{l}\text { Treatment = placebo on } \\
\text { outcome measures }\end{array}$ \\
\hline $\begin{array}{l}\text { Silvers et al. } \\
(2005) \text { [112] }\end{array}$ & $\begin{array}{l}N=77 \text { (18-65 yrs } \\
\text { recruited, mean age } 38), \\
\text { being treated for current } \\
\text { depressive episode }(53 \% \\
\text { female) }\end{array}$ & $\begin{array}{l}3 \mathrm{~g} / \text { day } n-3 \\
\text { PUFA }(2.4 \mathrm{~g} \\
\text { DHA ; } 0.6 \mathrm{~g} \\
\text { EPA }+ \text { Vit } \\
\text { E or olive oil } \\
\text { placebo }\end{array}$ & $\begin{array}{l}12 \text { weeks } \\
\text { parallel, } \\
\text { adjunctive } \\
\text { therapy }\end{array}$ & $\begin{array}{l}\text { HDRS short } \\
\text { form, BDI }\end{array}$ & $\begin{array}{l}\text { Treatment = placebo on } \\
\text { outcome measures } \\
\text { (improvements in both } \\
\text { groups at week 2) }\end{array}$ \\
\hline $\begin{array}{l}\text { Nemets et } \\
\text { al. }(2006) \\
{[105]}\end{array}$ & $\begin{array}{l}N=20 \text { (6-12 year old; } \\
25 \% \text { girls); children with } \\
\text { major depressive disorder }\end{array}$ & $\begin{array}{l}\text { 400mg EPA + } \\
200 \mathrm{mg} \\
\text { DHA/day or } \\
\text { safflower } \\
\text { oil/olive oil } \\
\text { placebos }\end{array}$ & $\begin{array}{l}16 \text { weeks, } \\
\text { parallel ( } 5 \\
\text { children } \\
\text { medicated) }\end{array}$ & $\begin{array}{l}{ }^{\mathrm{a} C D R S}, \mathrm{CDI} \text {, } \\
\text { CGI }\end{array}$ & $\begin{array}{l}\text { Treatment }>\text { placebo on } \\
\text { outcome measures }\end{array}$ \\
\hline $\begin{array}{l}\text { Grenyer et } \\
\text { al. }(2007) \\
{[113,114]}\end{array}$ & $\begin{array}{l}N=83 \text { (18-72 years, } M= \\
45 \text { ), outpatients with major } \\
\text { depression diagnosis }\end{array}$ & $\begin{array}{l}3 \mathrm{~g} / \text { day } n-3 \\
\text { PUFA }(2.2 \mathrm{~g} \\
\text { DHA, } 0.6 \mathrm{~g} \\
\text { EPA })+ \text { Vit E } \\
\text { or olive oil } \\
\text { placebo }\end{array}$ & $\begin{array}{l}4 \text { month } \\
\text { parallel } \\
\text { design, } \\
\text { adjunctive } \\
\text { therapy }\end{array}$ & $\begin{array}{l}\text { HDRS, BDI, } \\
\text { GAFS }\end{array}$ & $\begin{array}{l}\text { Treatment = placebo on } \\
\text { outcome measures } \\
\text { (improvements in both } \\
\text { groups) }\end{array}$ \\
\hline $\begin{array}{l}\text { Su et al. } \\
(2008) \text { [109] }\end{array}$ & $\begin{array}{l}N=24 \text { (18-40 years); with } \\
\text { major depressive disorder } \\
\text { during pregnancy }\end{array}$ & $\begin{array}{l}2.2 \mathrm{~g} \mathrm{EPA} \mathrm{+} \\
1.2 \mathrm{~g} \mathrm{DHA} \text { or } \\
\text { placebo, both } \\
\text { with } \\
\text { tocopherols \& } \\
\text { orange flavor }\end{array}$ & $\begin{array}{l}8 \text { weeks, } \\
\text { parallel } \\
\text { design }\end{array}$ & $\begin{array}{l}\text { HDRS, } \\
\text { EPDS, GDI }\end{array}$ & $\begin{array}{l}\text { Treatment }>\text { placebo on } \\
\text { outcome measures }\end{array}$ \\
\hline
\end{tabular}


Table 1. Cont.

\begin{tabular}{|c|c|c|c|c|c|}
\hline $\begin{array}{l}\text { Rogers et al. } \\
(2008) \text { [117] }\end{array}$ & $\begin{array}{l}N=190(18-70 \text { years } \\
\text { recruited, mean age }=38) ; \\
\text { people from GP surgeries } \\
\text { or public with mild- } \\
\text { moderate depression }(77 \% \\
\text { female })\end{array}$ & $\begin{array}{l}\text { 630mg EPA, } \\
850 \mathrm{mg} \text { DHA, } \\
870 \mathrm{mg} \text { olive } \\
\text { oil, or olive oil } \\
\text { placebo (both } \\
\text { with } \\
\text { tocopherols \& } \\
\text { orange oil) }\end{array}$ & $\begin{array}{l}12 \text { weeks } \\
\text { parallel } \\
\text { design }\end{array}$ & $\begin{array}{l}\text { DASS, BDI, } \\
\text { STAEI, } \\
\text { mood using } \\
\text { diary and } \\
\text { visual probe } \\
\text { task, } \\
\text { cognitive } \\
\text { function }\end{array}$ & $\begin{array}{l}\text { Treatment = placebo on } \\
\text { outcome measures } \\
\text { (improvements in both } \\
\text { groups) }\end{array}$ \\
\hline $\begin{array}{l}\text { Van de Rest } \\
\text { et al. }(2008) \\
{[118]}\end{array}$ & $\begin{array}{l}N=302 \text { ( }>65 \text { years, } M= \\
70 ; 55 \% \text { male) non- } \\
\text { depressed community } \\
\text { dwelling adults. } \\
\text { NCT00124852 }\end{array}$ & $\begin{array}{l}1.8 \mathrm{~g} / \text { day EPA } \\
+ \text { DHA, } \\
400 \mathrm{mg} / \text { day } \\
\text { EPA + DHA or } \\
\text { placebo }\end{array}$ & $\begin{array}{l}26 \text { weeks } \\
\text { parallel } \\
\text { design }\end{array}$ & $\begin{array}{l}\text { CES-D, } \\
\text { MADRS, } \\
\text { GDS-15, } \\
\text { HADQ, } \\
\text { [POMS short } \\
\text { form ( } n= \\
104)]\end{array}$ & $\begin{array}{l}\text { Treatment = placebo on } \\
\text { outcome measures }\end{array}$ \\
\hline $\begin{array}{l}\text { Freund-Levi } \\
\text { et al. }(2008) \\
{[115]}\end{array}$ & $\begin{array}{l}N=204 \text { (mean age } 73 \\
\text { years); people with AD } \\
\text { living in own homes, on } \\
\text { stable treatment with } \\
\text { acetylcholine esterase } \\
\text { inhibitors. NCT00211159 }\end{array}$ & $\begin{array}{l}1.72 \mathrm{~g} \text { DHA + } \\
600 \mathrm{mg} \\
\text { EPA/day or } \\
\text { corn oil } \\
\text { placebo }\end{array}$ & $\begin{array}{l}6 \text { months } \\
\text { parallel }+ \\
\text { one-way } \\
\text { crossover } \\
\text { to fish oil } \\
\text { for } 6 \\
\text { months }\end{array}$ & $\begin{array}{l}\text { NPI, } \\
\text { MADRS, } \\
\text { CGB, DAD }\end{array}$ & $\begin{array}{l}\text { Treatment = placebo on } \\
\text { outcome measures. } \\
\text { Treatment > placebo on } \\
\text { MADRS in non-apoE-4 } \\
\text { carriers and agitation in } \\
\text { apoE-4 carriers }\end{array}$ \\
\hline $\begin{array}{l}\text { Lucas et al. } \\
\text { (2009) [108] }\end{array}$ & $\begin{array}{l}N=120 \text { (recruited } 40-55 \\
\text { yrs; mean age } 49 \text { ) post- } \\
\text { menopausal women with } \\
\text { psychological distress \& } \\
\text { depressive symptoms }\end{array}$ & $\begin{array}{l}1.5 \mathrm{~g} \text { ethyl- } \\
\text { EPA, } 0.5 \mathrm{~g} \\
\text { ethyl-DHA }\end{array}$ & $\begin{array}{l}8 \text { weeks } \\
\text { parallel } \\
\text { design }\end{array}$ & $\begin{array}{l}\text { PGWB, } \\
\text { HSCL-D-20, } \\
\text { HDRS }\end{array}$ & $\begin{array}{l}\text { Treatment = placebo on all } \\
\text { measures (improvements in } \\
\text { both groups). Treatment }> \\
\text { placebo in women without } \\
\text { MDE (major depressive } \\
\text { episode diagnosis) }\end{array}$ \\
\hline $\begin{array}{l}\text { Carney et al. } \\
(2009)[116]\end{array}$ & $\begin{array}{l}N=122 ; \text { major depression } \\
+ \text { coronary heart disease } \\
\text { NCT00116857 }\end{array}$ & $\begin{array}{l}\text { 930mg ethyl- } \\
\text { EPA }+750 \mathrm{mg} \\
\text { ethyl DHA/day } \\
\text { or corn oil } \\
\text { placebo }\end{array}$ & $\begin{array}{l}10 \text { weeks } \\
\text { parallel } \\
\text { design, } \\
\text { adjunctive } \\
\text { therapy }\end{array}$ & $\begin{array}{l}\text { BDI-II; } \\
\text { HDRS }\end{array}$ & $\begin{array}{l}\text { Treatment = placebo on } \\
\text { outcome measures } \\
\text { (improvements in both } \\
\text { groups) }\end{array}$ \\
\hline $\begin{array}{l}\text { Stoll et al. } \\
\text { (1999) [120] }\end{array}$ & $\begin{array}{l}N=30 \text { ( } 18-65 \text { years); } \\
\text { inpatients with bipolar } \\
\text { disorder }\end{array}$ & $\begin{array}{l}9.6 \mathrm{~g} / \text { day } \mathrm{n}-3 \\
\text { PUFA }(6.2 \mathrm{~g} \\
\text { EPA, } 3.4 \mathrm{~g} \\
\text { DHA) or olive } \\
\text { oil esther } \\
\text { placebo }\end{array}$ & $\begin{array}{l}4 \text { month } \\
\text { parallel } \\
\text { design; } \\
\text { adjunctive } \\
\text { therapy }\end{array}$ & $\begin{array}{l}\text { HDRS, } \\
\text { YMRS, CGI- } \\
\text { S, GAS }\end{array}$ & $\begin{array}{l}\text { Treatment > placebo on } \\
\text { GAS, HDRS and CGI; } \\
\text { Treatment = placebo on } \\
\text { YMRS }\end{array}$ \\
\hline
\end{tabular}


Table 1. Cont.

\begin{tabular}{|c|c|c|c|c|c|}
\hline $\begin{array}{l}\text { Keck et al. } \\
(2006)[123]\end{array}$ & $\begin{array}{l}N=116 \text { ( } \mathrm{n}=57 \text { bipolar } \\
\text { depressed; } \mathrm{n}=59 \text { rapid } \\
\text { cycling), mean age: } 45 ; \\
51 \% \text { male }\end{array}$ & $\begin{array}{l}6 \mathrm{~g} / \text { day ethyl- } \\
\text { EPA or liquid } \\
\text { paraffin } \\
\text { placebo }\end{array}$ & $\begin{array}{l}4 \text { month } \\
\text { parallel } \\
\text { design; } \\
\text { adjunctive } \\
\text { therapy }\end{array}$ & $\begin{array}{l}\text { IDS, YMRS, } \\
\text { CGI-BP } \\
\text { (bipolar } \\
\text { disorder) }\end{array}$ & $\begin{array}{l}\text { Treatment }=\text { placebo on } \\
\text { outcome measures }\end{array}$ \\
\hline $\begin{array}{l}\text { Frangou et } \\
\text { al. (2006) } \\
{[124]}\end{array}$ & $\begin{array}{l}N=75 \text { (mean age: } 47) ; \\
\text { outpatients with bipolar } \\
\text { depression }+ \text { scores }>17 \\
\text { on HDRS }(76 \% \text { female })\end{array}$ & $\begin{array}{l}1 \mathrm{~g} / \text { day ethyl } \\
\text { EPA }(\mathrm{n}=24) \\
2 \mathrm{~g} / \text { day ethyl } \\
\text { EPA }(\mathrm{n}=25) \\
\text { or paraffin } \\
\text { placebo }\end{array}$ & $\begin{array}{l}12 \text { week } \\
\text { parallel } \\
\text { design, } \\
\text { adjunctive } \\
\text { therapy }\end{array}$ & $\begin{array}{l}\text { HDRS, } \\
\text { YMRS, CGI }\end{array}$ & $\begin{array}{l}\text { Treatment }>\text { placebo on } \\
\text { HDRS \& CGI on } 1 g \text { and } \\
2 g / \text { day. Treatment }= \\
\text { placebo on YMRS }\end{array}$ \\
\hline $\begin{array}{l}\text { Hallahan et } \\
\text { al. (2007) } \\
{[127]}\end{array}$ & $\begin{array}{l}N=49(16-64 \text { years, } M= \\
30) ; \text { presenting after act of } \\
\text { repeated self-harm }(65 \% \\
\text { women })\end{array}$ & $\begin{array}{l}1.2 \mathrm{~g} / \text { day EPA } \\
+0.9 \mathrm{~g} \text { DHA or } \\
\text { corn oil } \\
\text { placebo (with } \\
1 \% \text { EPA/DHA) }\end{array}$ & $\begin{array}{l}12 \text { weeks } \\
\text { parallel } \\
\text { design in } \\
\text { addition to } \\
\text { standard } \\
\text { care }\end{array}$ & $\begin{array}{l}\text { BDI, HDRS, } \\
\text { OAS-M, } \\
\text { IMT/DMT, } \\
\text { PSS, DHUS }\end{array}$ & $\begin{array}{l}\text { Treatment }>\text { placebo on } \\
\text { BDI, HDRS, PSS, DHUS. } \\
\text { Treatment = placebo on } \\
\text { OAS-M \& IMT/DMT } \\
\text { (hostility/aggression, } \\
\text { memory) }\end{array}$ \\
\hline $\begin{array}{l}\text { Peet et al. } \\
\text { (2001) [139] }\end{array}$ & $\begin{array}{l}\text { Study } 1: N=45 \text { (mean } \\
\text { age: } 44 \text { yrs); schizophrenic } \\
\text { patients, PANSS score }> \\
40 \\
\text { Study 2: } N=30 \text { (mean age } \\
35 \text { years); diagnosed } \\
\text { schizophrenia, untreated }\end{array}$ & $\begin{array}{l}2 \mathrm{~g} \text { EPA, } 2 \mathrm{~g} \\
\text { DHA or } \\
\text { placebo } \\
2 \mathrm{~g} / \text { day EPA or } \\
\text { corn oil } \\
\text { placebo }\end{array}$ & $\begin{array}{l}3 \text { months } \\
\text { parallel } \\
\text { adjunctive } \\
\text { therapy } \\
3 \text { months } \\
\text { parallel, } \\
\text { single } \\
\text { therapy } \\
\text { unless } \\
\text { drugs } \\
\text { needed }\end{array}$ & $\begin{array}{l}\text { PANSS; need } \\
\text { for } \\
\text { antipsychotic } \\
\text { medication }\end{array}$ & $\begin{array}{l}\text { EPA treatment }>\text { placebo } \\
\text { or DHA on positive PANSS } \\
\text { score. Treatment = placebo } \\
\text { on negative symptoms } \\
\text { score } \\
\text { Treatment }>\text { placebo, } \\
\text { particularly on positive } \\
\text { subscale; } 12 / 12 \text { placebo } \\
\text { and } 8 / 14 \text { EPA patients took } \\
\text { medication }\end{array}$ \\
\hline $\begin{array}{l}\text { Fenton et al. } \\
(2001)[141]\end{array}$ & $\begin{array}{l}N=87 \text { (18-65 years, } M= \\
40 ; 61 \% \text { male) diagnosed } \\
\text { schizophrenia or } \\
\text { schizoaffective disorder }\end{array}$ & $\begin{array}{l}3 \mathrm{~g} / \text { day ethyl } \\
\text { EPA }+ \text { Vit E or } \\
\text { mineral oil }+ \\
\text { Vit E placebo }\end{array}$ & $\begin{array}{l}16 \text { week } \\
\text { parallel } \\
\text { design, } \\
\text { adjunctive } \\
\text { therapy }\end{array}$ & $\begin{array}{l}\text { PANSS, } \\
\text { CGI, } \\
\text { MADRS, } \\
\text { RBANS, } \\
\text { AIMS, SARS }\end{array}$ & $\begin{array}{l}\text { Treatment = placebo on } \\
\text { outcome measures (some } \\
\text { showed improvements in } \\
\text { both groups) }\end{array}$ \\
\hline $\begin{array}{l}\text { Emsley et al. } \\
(2002)[138]\end{array}$ & $\begin{array}{l}N=40(18-55 \text { years, } M= \\
45) ; \text { schizophrenic, } \\
\text { treatment resistant } \\
\text { patients, PANSS score }> \\
10\end{array}$ & $\begin{array}{l}3 \mathrm{~g} / \text { day ethyl- } \\
\text { EPA or liquid } \\
\text { paraffin } \\
\text { placebo }\end{array}$ & $\begin{array}{l}12 \text { weeks } \\
\text { parallel } \\
\text { design, } \\
\text { adjunctive } \\
\text { therapy }\end{array}$ & $\begin{array}{l}\text { PANSS, } \\
\text { ESRS }\end{array}$ & $\begin{array}{l}\text { Treatment }>\text { placebo on } \\
\text { PANSS and dykinesia } \\
\text { subscale of ESRS. } \\
\text { Treatment = placebo on } \\
\text { other ESRS subscales }\end{array}$ \\
\hline
\end{tabular}


Table 1. Cont.

\begin{tabular}{|c|c|c|c|c|c|}
\hline $\begin{array}{l}\text { Peet \& } \\
\text { Horrobin } \\
(2002)[140]\end{array}$ & $\begin{array}{l}N=115(20-62 \text { years, } M= \\
37 ; 66 \% \text { male }) \text {, treatment- } \\
\text { resistant schizophrenia; } \\
\text { PANSS }>50\end{array}$ & $\begin{array}{l}1,2 \text { or } 4 \mathrm{~g} / \text { day } \\
\text { ethyl-EPA or } \\
\text { liquid paraffin } \\
\text { placebo }\end{array}$ & $\begin{array}{l}12 \text { weeks } \\
\text { parallel } \\
\text { design, } \\
\text { adjunctive } \\
\text { therapy }\end{array}$ & $\begin{array}{l}\text { PANSS, } \\
\text { LUNSERS, } \\
\text { MADRS, } \\
\text { AIMS, BAS, } \\
\text { SARS }\end{array}$ & $\begin{array}{l}\text { Treatment }=\text { placebo on all } \\
\text { rating scales; } 2 \mathrm{~g} \text { treatment } \\
>\text { placebo for patients on } \\
\text { clozapine (associated with } \\
\uparrow A A \text { ) }\end{array}$ \\
\hline $\begin{array}{l}\text { Berger et al. } \\
(2007)[144]\end{array}$ & $\begin{array}{l}N=69 \text { (mean age } 21 \pm 4 \\
76 \% \text { male) first episode } \\
\text { psychosis patients }\end{array}$ & $\begin{array}{l}2 \mathrm{~g} / \text { day ethyl- } \\
\text { EPA or mineral } \\
\text { oil placebo not } \\
\text { absorbed by } \\
\text { intestinal tract } \\
\text { (both with } \\
\text { Vitamin E) }\end{array}$ & $\begin{array}{l}12 \text { weeks } \\
\text { parallel } \\
\text { design, } \\
\text { adjunctive } \\
\text { therapy }\end{array}$ & $\begin{array}{l}\text { BPRS, } \\
\text { SANS, } \\
\text { CDSS, CGI, } \\
\text { GAF, } \\
\text { SOFAS }\end{array}$ & $\begin{array}{l}\text { Treatment }=\text { placebo on all } \\
\text { outcome measures. } \\
\text { Treatment }>\text { placebo on } \\
\text { CGI co-varying for } \\
\text { duration of untreated } \\
\text { psychosis; treatment }> \\
\text { placebo at weeks } 4-6\end{array}$ \\
\hline $\begin{array}{l}\text { Amminger } \\
\text { et al. }(2010) \\
{[145]}\end{array}$ & $\begin{array}{l}N=81(13-25 \text { years, } \mathrm{M}= \\
16 \pm 2,40 \% \text { male }), \text { met } \\
\text { defined risk factors for } \\
\text { psychosis }\end{array}$ & & & & \\
\hline $\begin{array}{l}\text { Hamazaki et } \\
\text { al. (1996) } \\
{[147]}\end{array}$ & $\begin{array}{l}N=41 \text { (19-30 years, } 70 \% \\
\text { female); university } \\
\text { students (study measured } \\
\text { aggression and executive } \\
\text { function) }\end{array}$ & $\begin{array}{l}1.5-1.8 \mathrm{~g} / \mathrm{day} \\
\text { DHA or } 97 \% \\
\text { soybean oil + } \\
3 \% \text { fish oil } \\
\text { placebo } \\
\text { capsules }\end{array}$ & $\begin{array}{l}3 \text { months } \\
\text { parallel } \\
\text { design }\end{array}$ & $\begin{array}{l}\text { P-F Study; } \\
\text { Stroop; } \\
\text { Dementia- } \\
\text { detecting test }\end{array}$ & $\begin{array}{l}\text { Treatment }>\text { placebo on } \\
\text { extragression (increased in } \\
\text { placebo group during exam } \\
\text { time); treatment = placebo } \\
\text { on other measures }\end{array}$ \\
\hline $\begin{array}{l}\text { Gesch et al. } \\
(2002)[150]\end{array}$ & $\begin{array}{l}N=172 \text { (male offenders }> \\
18 \text { years); prison inmates }\end{array}$ & $\begin{array}{l}\text { Vitamin and } \\
\text { mineral } \\
\text { supplement }+ \\
80 \mathrm{mg} \text { EPA, } \\
44 \mathrm{mg} \text { DHA, } \\
1.26 \mathrm{~g} \text { ALA or } \\
\text { veg oil placebo }\end{array}$ & $\begin{array}{l}20 \text { weeks, } \\
\text { parallel } \\
\text { design }\end{array}$ & $\begin{array}{l}\text { No. } \\
\text { disciplinary } \\
\text { actions; } \\
\text { GATB; ECQ; } \\
\text { SAS; HADQ }\end{array}$ & $\begin{array}{l}\text { Treatment }>\text { placebo on } \\
O A S-M \& M A D R S\end{array}$ \\
\hline $\begin{array}{l}\text { Zanarini et } \\
\text { al. }(2003) \\
{[149]}\end{array}$ & $\begin{array}{l}N=30 \text { (18-40 years; } M= \\
26) ; \text { females with } \\
\text { moderately severe } \\
\text { borderline personality } \\
\text { disorder }\end{array}$ & $\begin{array}{l}\text { 1g/day ethyl- } \\
\text { EPA or mineral } \\
\text { oil placebo }\end{array}$ & $\begin{array}{l}8 \text { weeks } \\
\text { parallel } \\
\text { design }\end{array}$ & $\begin{array}{l}\text { OAS-M; } \\
\text { MADRS }\end{array}$ & $\begin{array}{l}\text { Treatment }>\text { placebo no. } \\
\text { disciplinary actions } \\
\text { Treatment = placebo on } \\
\text { psychological measures }\end{array}$ \\
\hline
\end{tabular}


Table 1. Cont.

\begin{tabular}{|c|c|c|c|c|c|}
\hline $\begin{array}{l}\text { Bradbury et } \\
\text { al. }(2004) \\
{[148]}\end{array}$ & $\begin{array}{l}\text { Stressed university staff } \\
\text { (PSS scores } \geq 17 \text { ) } \\
\text { ISRCTN22569553 }\end{array}$ & $\begin{array}{l}1.5 \mathrm{~g} \mathrm{DHA}+ \\
360 \mathrm{mg} \text { EPA }+ \\
\text { Vit E, olive oil } \\
\text { placebo, or no } \\
\text { treatment } \\
\text { control }\end{array}$ & $\begin{array}{l}6 \text { weeks } \\
\text { parallel } \\
\text { design }\end{array}$ & PSS & $\begin{array}{l}\text { Treatment }=\text { placebo on } \\
\text { PSS; treatment }>\text { no } \\
\text { treatment control }\end{array}$ \\
\hline $\begin{array}{l}\text { Buydens- } \\
\text { Branchey et } \\
\text { al. }(2008) \\
{[156]}\end{array}$ & $\begin{array}{l}N=24 \text { (mean age } 51 \\
\text { years); patients with } \\
\text { history of aggression }\end{array}$ & $\begin{array}{l}2.5 \mathrm{~g} \mathrm{EPA}+ \\
0.5 \mathrm{~g} \mathrm{DHA} / \text { day } \\
+ \text { Vit E or } \\
\text { soybean oil }+ \\
\text { Vit E placebo }\end{array}$ & $\begin{array}{l}3 \text { months } \\
\text { parallel } \\
\text { design, } \\
\text { most } \\
\text { taking } \\
\text { medication }\end{array}$ & $\begin{array}{l}\text { Anger score } \\
\text { on POMS }\end{array}$ & $\begin{array}{l}\text { Treatment }>\text { placebo on } \\
\text { POMS anger scores }\end{array}$ \\
\hline $\begin{array}{l}\text { Yehuda et } \\
\text { al. (1996) } \\
{[168]}\end{array}$ & $\begin{array}{l}N=100(50-73 \text { years; } 21 \% \\
\text { females }) \text { AD patients }\end{array}$ & $\begin{array}{l}0.5 \mathrm{~g} \text { ALA }: \text { LA, } \\
1: 4 \text { ratio }(\mathrm{n}= \\
60) \text { or mineral } \\
\text { oil placebo }\end{array}$ & $\begin{array}{l}4 \text { weeks } \\
\text { parallel } \\
\text { design, } \\
\text { adjunctive } \\
\text { therapy }\end{array}$ & $\begin{array}{l}\text { 12-item } \\
\text { quality of life } \\
\text { questionnaire } \\
\text { (caregiver), } \\
\text { clinician } \\
\text { interview }\end{array}$ & $\begin{array}{l}\text { Treatment > placebo on } \\
\text { 12-item QOL } \\
\text { questionnaire. } \\
\text { Clinician interviews not } \\
\text { reported. }\end{array}$ \\
\hline $\begin{array}{l}\text { Terano et al. } \\
\text { (1999) [169] }\end{array}$ & $\begin{array}{l}N=20 \text { (mean age } 83 \text { ) } \\
\text { nursing home residents } \\
\text { with mild-moderate } \\
\text { vascular dementia }\end{array}$ & $\begin{array}{l}4.32 \mathrm{~g} / \text { day } \\
\text { DHA or } \\
\text { 'control' }\end{array}$ & $\begin{array}{l}12 \text { months } \\
\text { parallel } \\
\text { design }\end{array}$ & $\begin{array}{l}\text { MMSE; } \\
\text { HDS-R; } \\
\text { clinical } \\
\text { evaluation }\end{array}$ & $\begin{array}{l}\text { Treatment }>\text { placebo on } \\
\text { outcome measures after } 3 \\
\& 6 \text { months, associated } \\
\text { with DHA increases }\end{array}$ \\
\hline $\begin{array}{l}\text { Kotani et al. } \\
(2006)[171]\end{array}$ & $\begin{array}{l}N=21 \text { (mean age } 68 ; 57 \% \\
\text { male); outpatients with } \\
\text { MCI }\end{array}$ & $\begin{array}{l}240 \mathrm{mg} / \text { day } \\
\text { AA+DHA or } \\
\text { olive oil } \\
\text { placebo }\end{array}$ & $\begin{array}{l}3 \text { months } \\
\text { parallel } \\
\text { design }\end{array}$ & $\begin{array}{l}\text { RBANS } \\
\text { (Japanese } \\
\text { version) }\end{array}$ & $\begin{array}{l}\text { Treatment }>\text { placebo on } \\
\text { immediate memory \& } \\
\text { attention. Treatment }= \\
\text { placebo on other } 10 \text { sub- } \\
\text { scales }\end{array}$ \\
\hline $\begin{array}{l}\text { Freund-Levi } \\
\text { et al. }(2006) \\
{[172]}\end{array}$ & $\begin{array}{l}N=178 \text { (mean age } 74) \\
\text { mild-moderate } \mathrm{AD} \\
\text { patients NCT00211159 }\end{array}$ & $\begin{array}{l}1.72 \mathrm{~g} \mathrm{DHA}+ \\
600 \mathrm{mg} \\
\text { EPA/day or } \\
\text { placebo }\end{array}$ & $\begin{array}{l}6 \text { months } \\
\text { parallel } \\
\text { design, } \\
\text { adjunctive } \\
\text { therapy }\end{array}$ & $\begin{array}{l}\text { MMSE, } \\
\text { ADAS-cog; } \\
\text { global } \\
\text { function on } \\
{ }^{\mathrm{b}} \mathrm{CDRS}\end{array}$ & $\begin{array}{l}\text { Treatment }=\text { placebo on } \\
\text { outcome measures. } \\
\text { Treatment }>\text { placebo on } \\
\text { MMSE in mild MCI group } \\
(n=27)\end{array}$ \\
\hline $\begin{array}{l}\text { Chiu et al. } \\
\text { (2008) [173] }\end{array}$ & $\begin{array}{l}N=35 \text { (mean age } 74 ; 57 \% \\
\text { female); AD or MCI }\end{array}$ & $\begin{array}{l}1.08 \mathrm{~g} \mathrm{EPA}+ \\
.72 \mathrm{~g} \mathrm{DHA} \text { or } \\
\text { olive oil } \\
\text { placebo }\end{array}$ & 6 months & $\begin{array}{l}\text { CIBIC-plus; } \\
\text { ADAS-cog; } \\
\text { MMSE; } \\
\text { HDRS }\end{array}$ & $\begin{array}{l}\text { Treatment }>\text { placebo on } \\
\text { CIBIC-plus. Treatment }= \\
\text { placebo on other measures. } \\
\text { Treatment }>\text { placebo on } \\
\text { ADAS-cog in MCI sub- } \\
\text { group }\end{array}$ \\
\hline
\end{tabular}


Table 1. Cont.

\begin{tabular}{|c|c|c|c|c|c|}
\hline $\begin{array}{l}\text { van de Rest } \\
\text { et al. (2008) } \\
{[174]}\end{array}$ & $\begin{array}{l}N=302 \text { (mean age } 70 \\
\text { years; 55\% male) } \\
\text { community non-demented } \\
\text { dwelling adults NTR97; } \\
\text { ISRCTN46249783 }\end{array}$ & $\begin{array}{l}1.8 \mathrm{~g} / \text { day } \\
\text { EPA+DHA; } \\
400 \mathrm{mg} / \text { day } \\
\text { EPA + DHA; } \\
\text { or sunflower } \\
\text { oil placebo; } \\
\text { tocopherol } \\
\text { added }\end{array}$ & $\begin{array}{l}26 \text { weeks } \\
\text { parallel } \\
\text { design }\end{array}$ & $\begin{array}{l}\text { Word } \\
\text { Learning } \\
\text { Task; Digit } \\
\text { Span; Trail } \\
\text { Making; } \\
\text { Stroop; } \\
\text { Verbal } \\
\text { Fluency }\end{array}$ & $\begin{array}{l}\text { Treatment = placebo on } \\
\text { outcome measures; } \\
\text { Treatment }>\text { placebo on } \\
\text { attention for apoE-4 } \\
\text { carriers and males }\end{array}$ \\
\hline
\end{tabular}

Note: Trials are grouped according to subheadings in main text (e.g., ADHD, depression, etc.) *Positive treatment effects are presented in italic. AD = Alzheimer's Disease; ADAS-cog $=$ cognitive portion of the Alzheimer's Disease Assessment Scale; ADHD = attention deficit hyperactivity disorder; AIMS = Abnormal Involuntary Movement Scale; ASQ = Conners' Abbreviated Symptom Questionnaires; BDI = Beck Depression Inventory; BPRS = Brief Psychiatric Rating Scale; $\mathrm{CBC}=$ Child Behavior Checklist; $\mathrm{CCT}=$ Children's Color Trails test; $\mathrm{CDI}=$ Childhood Depression Inventory; ${ }^{\mathrm{a}} \mathrm{CDRS}=$ Childhood Depression Rating Scale; ${ }^{\mathrm{b}} \mathrm{CDRS}=$ Clinical Dementia Rating Scale; CDSS = Calgary Depression Scale for Schizophrenia; CES-D = Centre for Epidemiologic Studies Depression Scale; CGB = Caregivers Burden Scale; CGI-S = Clinical Global Impression-Severity; CIBIC-plus = Clinician's Interview-Based Impression of Change Scale; CPRS = Conners' Parent Rating Scales; CPT = Conners' Continuous Performance Test; CTRS $=$ Conners' Teacher Rating Scales; DAD = Disability Assessment for Dementia scale; DASS = Depression \& Anxiety Stress Scale; DBD = Disruptive Behavior Disorders rating scale; DHUS: Daily Hassles \& Uplifts Scale; DMT: Delayed Memory Task; DSM-IV = Diagnostic and Statistical Manual of Mental Disorders, version 4; DTVP = Development Test of Visual Perception; ECQ $=$ Emotional Control Questionnaire; EPDS $=$ Edinburgh Postnatal Depression Scale; ESRS = Extrapyramidal Symptom Rating Scale; FADS = fatty acid deficiency symptoms; GAFS = Global Assessment of Functioning Scale (revised GAS); GAS = Global Assessment Scale; GATB = General Aptitude Test Battery; GDS = Geriatric Depression Scale; HADQ = Hospital Anxiety \& Depression Questionnaire; HDRS = Hamilton Depression Rating Scale; HSCL-D-20 = 20-item Hopkins Symptom Checklist Depression Scale; IDS = Inventory for Depressive Symptomology; IMT = Immediate Memory Task; LUNSERS = Liverpool University Neuroleptic Side-Effects Rating Scale; MABC = Movement Assessment Battery for Children; MADRS = Montgomery-Asberg Depression Rating Scale; MCI = Mild Cognitive Impairment; MMSE = Mini-Mental State Examination; NPI = Neuropsychiatric Inventory; OAS-M = The Overt Aggression Scale, Modified; PANSS = Positive and Negative Syndrome Scale; PGWB = Psychological General Well-Being Schedule; P-F Study: measures aggression, including extra- \& intra-aggression; POMS = Profile of Mood States; PSS: Perceived Stress Scale; RBANS = Repeatable Battery for the Assessment of Neuropsychological Status; SANS = Scale for the Assessment of Negative Symptoms; SARS = Simpson-Angus Rating Scale; SAS = Survey Anger Scales; SOFAS = Social and Occupational Functioning Assessment Scale; STAEI = State-Trait Anger Expression Inventory; Stroop = 
Stroop color-word test; STM = Short-term memory; TEA-ch = Test of Everyday Attention for children; TOVA = Test of Variables of Attention; Vit E = Vitamin E ( $\alpha$-tocopheryl acetate); WISC-III = Wechsler Intelligence Scale for Children, version 3; WORD $=$ Wechsler Objective Reading Dimensions; WJPEB-R = Woodstock-Johnston Psycho-Educational Battery - Revised; YMRS = Young Mania Rating Scale

\subsection{Attention Deficit Hyperactivity Disorder (ADHD)}

Increasing attention has been given to the role of EFA in childhood developmental disorders. Given that brain development continues throughout childhood $[42,43]$, PUFA supplementation may also have a beneficial effect during developmental milestones, particularly in children with developmental disorders that might be related to problems with PUFA metabolism and/or deficiency.

Since the 1980s, researchers have identified lower levels of n-3 and n-6 PUFA in blood analyses of hyperactive children compared with matched controls [44-51]. Therefore a growing number of clinical trials are investigating effects of PUFA supplementation on ADHD-related symptoms.

Early intervention trials were reported to show little or no improvement in alleviating hyperactive symptoms of ADHD with evening primrose oil, which contains the n-6 PUFA GLA [44,52]. Following these studies and with increasing awareness of the importance of n-3 PUFA, 8 randomised, doubleblind, placebo-controlled PUFA supplementation trials have been completed with children displaying ADHD-related symptoms, with varying results. These could be attributed to methodological differences such as variations in dosage, PUFA formulation, period of supplementation, selection criteria and outcome measures.

In the first study, supplementation with $345 \mathrm{mg}$ of DHA per day over four months in 6-12 year old children diagnosed with ADHD did not significantly improve objective or subjective measurements of symptoms, even though there was a significant increase in RBC levels of DHA in the DHA group [53]. In this study, stimulant medication ceased 24 hours before laboratory measurements. However, parents completed the subjective scales (Child Behavior Checklist and Conners' Rating Scales) while the children were still receiving stimulant medication. This may have influenced the results by masking their symptoms and making it difficult to detect any improvements; closer inspection confirms that tscores on parent rating scales were in the normal range before supplementation. Moreover, children who had experienced ineffective treatment with stimulant medication or had a previous diagnosis of mood, anxiety, thought or bipolar disorder were excluded from the study. It is presumed that the rationale for this was to select a group of children with 'pure' ADHD symptoms. This may not be entirely practical due to the high co-morbidity prevalent in ADHD and, as discussed by Richardson [54], the heterogeneity of ADHD and its overlap with other neurodevelopmental disorders needs to be explored within a phospholipid framework.

Another study using both DHA and EPA (supplemented in fish oil-enriched bread, supplying 3600mg DHA and 700mg EPA per week, or 514mg DHA and 100mg EPA per day) [55] also found no significant treatment effects on ADHD symptoms, in a two month placebo-controlled, double-blind trial with 40 children aged 6-12 who were mostly drug-free (34/40). The placebo bread contained olive oil. Paradoxically, the control group had significant improvements in visual short-term memory and errors of commission that were not seen in the treatment group. Blood samples were not taken, so it is 
not clear whether this sample had low n-3 PUFA levels at baseline. Given that the study was conducted in Japan, known to have high fish consumption, it is likely that baseline levels were relatively high. It is also possible that two months may have been insufficient time for effects to become observable, as it may take longer to elevate the fatty acid composition of neural membranes [56,57].

Five other interventions reported improvements in symptoms with a combination of n-6 and n-3 PUFA, including both EPA and DHA. In a pilot study, 41 British children aged 8-12 years with ADHD-related symptoms and specific learning disabilities (dyslexia) were given a PUFA supplement or olive oil placebo over 12 weeks [58]. The PUFA supplement in this study provided a daily dose of 186mg EPA, 480mg DHA, 864mg LA and 42mg AA, as well as $\alpha$-tocopherol (Vitamin E). These children all had above average scores on parent ratings of ADHD symptoms, and average general ability yet low reading achievement. Baseline measures on learning and behaviour did not differ between the groups, but the PUFA group showed improvements on global ADHD indices and subscale ratings of cognitive problems/inattention, hyperactivity, restlessness/impulsivity, psychosomatic complaints and anxiety/shyness on Conners' Parent Rating Scale following 12 weeks of supplementation, with medium effect sizes reported.

Similarly, another study investigated effects of PUFA supplementation, providing a daily dose of 80mg EPA, 480mg DHA, 40mg AA, 96g GLA and 24mg $\alpha$-tocopherol, or olive oil placebo, over four months in American children with ADHD-like symptoms, selected for thirst and skin problems indicative of fatty acid deficiency [59]. Plasma proportions of DHA, EPA and $\alpha$-tocopherol increased in the intervention group following supplementation and there was a significant drop in n-6 to n-3 ratios, although the olive oil group demonstrated a small increase in ALA. Significant treatment effects were found for only 2 of 16 outcome measures when compared to placebo: parent ratings of conduct and teacher ratings of attention. Oppositional defiant behavior scores significantly improved from clinical to non-clinical levels, and significant relationships were reported between the change in RBC PUFA and the magnitude of improvements in outcome measures. Increased levels of EPA and DHA were associated with decreases in teacher ratings of inattention and increased levels of EPA with parent ratings of reduced disruptive behaviour. Methodological issues in this study included increased n-3 plasma levels in the placebo (olive oil) group and small sample size ( $N=50$ plus 17 dropouts).

Two larger double-blind, placebo-controlled trials investigated effects of PUFA on ADHD symptoms. The first study [60] included 117 children diagnosed with dyspraxia, or Developmental Coordination Disorder (DCD), and a third of the sample had scores $\geq 2$ SD above the population mean on the DSM-IV ADHD subscale of Conners' Teacher Rating Scales (CTRS). The children were functioning on average about a year behind their chronological age in reading and spelling. The active supplement provided a high ratio of EPA:DHA with a daily dose of $552 \mathrm{mg}$ EPA, $168 \mathrm{mg}$ DHA, 60mg DGLA and $9.6 \mathrm{mg} \alpha$-tocopherol. Although no improvements were detected on the core DCD symptom of poor motor function after three months, highly significant improvements were reported in reading and spelling in the treatment group compared to placebo over three months and significant treatment effects were observed for teacher ratings of oppositional behaviour, cognitive problems/inattention, hyperactivity, anxiety/shyness, and global/DSM-IV ADHD. Following a one-way, uncontrolled 
crossover to active treatment for a further three months, the placebo group demonstrated similar improvements in mean scores, while the original treatment group's scores continued to improve.

The second large intervention included 132 Australian children, all with ADHD symptoms $>90^{\text {th }}$ percentile and therefore in the clinical range for a diagnosis [61]. Children received the same treatment as above (a daily dose of $552 \mathrm{mg}$ EPA, $168 \mathrm{mg}$ DHA, 60mg DGLA and $9.6 \mathrm{mg} \alpha$-tocopherol) with or without a micronutrient supplement or placebo for 15 weeks, and then all groups crossed over to active treatment for a further 15 weeks. Significant improvements were observed on parent ratings of inattention, hyperactivity and impulsivity in both PUFA groups over 15 weeks, which were then mirrored in the placebo group after switching to active treatment for 15 weeks. Objective improvements were found in children's ability to switch and control their attention, and on vocabulary scores, and these mediated parent-reported improvements in hyperactivity, impulsivity and inattention [62]. This study also found that the fatty acid deficiency symptoms used as a selection criterion by Stevens et al. [59] improved in both the treatment and placebo groups over 15 weeks, and concluded that these symptoms are more likely to be an indicator of n-6 rather than n-3 deficiency [63].

A more recent study was conducted in Sweden with a similar supplement and study design as the previous two large trials, but including 75 children aged 8-18 years with ADHD [64]. They did not detect significant improvements overall; however, when dividing the sample into subgroups, they found that children with the inattentive subtype of ADHD and associated neurodevelopmental disorders, i.e. autistic symptoms and learning difficulties, showed similar clinical improvements as the previous large studies.

Therefore, there is evidence that children with ADHD-related symptoms may respond to PUFA supplementation and that those with the attention subtype and/or learning difficulties may be more likely to respond. Interestingly, studies using a combination of n-3 and n- 6 fatty acids have been more effective than those with DHA or GLA (DGLA precursor) alone. However, the relative importance of EPA, DHA and GLA remain to be determined due to methodological differences between the studies. Our group has recently completed a 12 month trial with 7-12 year old children with ADHD in Adelaide and Brisbane, Australia, in a 3 x 3 crossover design comparing EPA-rich and DHA-rich oils with an LA placebo. At baseline higher DHA was associated with improved reading (although not quite significant after controlling for confounders) and higher AA with poorer reading, spelling, vocabulary and attention. Interestingly, children with learning difficulties (behind age level on literacy; $n=30$ with bloods) had lower DHA and total n-3 and higher n-6 PUFA levels, although only the DHA relationship remained significant after controlling for differences in age and parent-reported health [65]. Preliminary results indicate that, although there were no significant between-group differences over 4-months, in children who consented to have blood taken increased erythrocyte DHA was associated with improved parent ratings of oppositional behaviour, anxiety/shyness, divided attention and reading $(n=45)$. In the subgroup with learning difficulties $(n=16$ with bloods at both time points) increased erythrocyte DHA had even stronger associations with improved parent ratings of oppositional behaviour, hyperactivity, restlessness/impulsivity, divided attention, reading and spelling [66]. These preliminary data indicate that DHA supplementation may be associated with improved ADHD symptoms and that children with learning difficulties may be more likely to benefit, 
supporting a phospholipid spectrum hypothesis that suggests these symptoms occur on a continuum of overlapping and related developmental difficulties [54]. However, the latter sample size was small due to difficulties with recruitment/eligibility and need to be investigated further in larger samples.

Other randomized controlled trials with ADHD and n-3 PUFA are underway in Israel, the UK and France, as listed in Table 2.

\subsection{Other Developmental Disorders}

PUFA have also been implicated in other, often related developmental disorders such as autistic spectrum disorder [67,68] and dyslexia [69-74]. There is some evidence to suggest that autism may involve functional deficiencies or imbalances in n-3 PUFA. Studies on the profiles of PUFA in children with autism that have found defects of PUFA and phospholipids, the major constituent of cell membranes, have had conflicting results. Vancassel et al. examined plasma phospholipid fatty acids in a population of children with autism compared to intellectually disabled controls [75]. They reported a $23 \%$ reduction of DHA levels in the children with autism compared with controls. Reduced RBC levels of n-3 PUFA and increased levels of saturated fatty acids (SFA) have also been reported in individuals with autism [67,68]. Additionally, there is evidence that n-3 PUFA can assist in inflammatory bowel disorders [76], which are often found in children with autism and may play a role in its etiology [77].

Few studies have investigated effects of n-3 PUFA supplementation in autism. A case report noted improvements in symptoms of a boy with autism following EPA supplementation that was increased from $1 \mathrm{~g}$ per day to $3 \mathrm{~g}$ per day over four weeks, with improvements continuing after an eight-month follow-up [78]. An uncontrolled open-label study completed by 18 out of 20 children reported significant within-group improvements after three months of combined n-3, n-6 and n-9 PUFA supplementation (1g/day) [79]. Only one randomized controlled trial (RCT) trialing n-3 PUFA supplementation in autism has been published [80]. This six-week pilot RCT in 13 children with autism reported a trend for improvements in hyperactivity and stereotypy in the group receiving n-3 PUFA. Menhaden fish oil was used with daily doses of $840 \mathrm{mg}$ EPA and $700 \mathrm{mg}$ DHA.

A three-month crossover RCT was conducted in Durham by Dr Madeleine Portwood, and is yet to be published. The daily doses of PUFA used were $558 \mathrm{mg}$ EPA and $174 \mathrm{mg}$ DHA. Results regarding outcome measures were inconclusive and postulated to be due to failure to reach a ceiling effect of the PUFA over three months. After a one-way crossover, however, improvements were reportedly observed after six months of active n-3 PUFA supplementation. Therefore it was concluded that further studies examining active versus placebo treatment over six months are warranted. As with previous large studies that extended the treatment period in a one-way crossover $[60,61]$, this study indicates the importance of the length of supplementation relative to dosage for improvements to be observed. Considering the complexity of autism, n-3 PUFA may also be best investigated as an adjunctive therapy. Therefore, studies are limited and results are inconclusive. A study is currently underway in the US investigating n-3 PUFA for treatment of hyperactivity in children with autism and another registered study aiming to investigate n-3 PUFA supplementation in children and adolescents with autistic spectrum disorder aimed to complete in 2007 but does not appear to have published results (see Table 2). 


\subsection{Mental Retardation}

To date, fatty acid researchers have not focused specifically on the heterogeneous group of disorders that characterize mental retardation. Many people with mental retardation are likely to display co-morbid symptoms including hyperactivity, impulsivity, aggression, anxiety, and DSM-IV diagnosed psychiatric disorders such as bipolar disorder, schizophrenia [81] and ADHD [82]. It has been suggested that the high rate of psychiatric disorders in children and adolescents with mental retardation might be a major problem in their functioning and adaptation [83]. The impact of PUFA for the amelioration of learning, cognition and behavior control problems in developmental disorders like ADHD may have implications for the treatment of these same difficulties in people with mental retardation. This is important, particularly given that there are indications that some forms of mental retardation might be caused by defects in the structure and functioning of neural synapses [84], which are rich in the n-3 PUFA, DHA. For a more in-depth discussion see Sinn and Wilson [85].

\subsection{Depression and Suicide Ideation}

PUFA deficiency is also implicated in depression. Along with cardiovascular disease (CVD), depression seems to be more prevalent in countries where fish consumption is lower, after controlling for demographic variables and potentially confounding factors such as alcohol intake [86-90]. It is well established that depression often co-occurs with CVD, which is associated with elevated cholesterol and lower PUFA levels, and studies have confirmed that depression does not result from CVD as it has been found to exist before symptoms of CVD set in [91]. Indicative of a common underlying biological component, higher serum AA:EPA ratios were reported in depressed post-myocardial infarction patients [92] and lower total n-3 PUFA and DHA levels in depressed patients recovering from acute coronary syndromes [93] than in similar patients without depression. Shared PUFA abnormalities might further account for the depression that co-occurs with stress, post-natal depression, autoimmune diseases, multiple sclerosis, cancer, diabetes, aging and osteoporosis [91]. A number of studies have found lower n-3 PUFA levels or higher AA/EPA ratios in people with depression compared with controls [21,94-99], including a postmortem comparison of 15 patients with major depressive disorder (MDD) versus 27 controls - specifically lower DHA levels in the frontal cortex [100].

A case study reported improvement in treatment-resistant depression when EPA was added to the conventional treatment, which was also associated with reduced neuronal phospholipid turnover and structural brain changes over the nine months of treatment [101]. Clinical trials have been previously reviewed [41, 102], although new studies have since been published. Six trials used high EPA supplements. In a small dose-ranging study, treatment with $1 \mathrm{~g}$ /day of ethyl-EPA but not 2 or $4 \mathrm{~g} /$ day was effective in improving depressive symptoms in adults with ongoing depression whilst continuing their standard medication [103]. However, another small study reported positive treatment effects with $2 \mathrm{~g}$ ethyl-EPA as an adjunctive therapy compared with placebo over four weeks [104]. This group also conducted a study with 6-12 year old children with major depressive disorder [105]. Only five of the twenty children were medicated, and following sixteen weeks of 400mg EPA plus 200mg DHA per day, the treatment group showed significant improvements in symptoms on all outcome measures. 
It should be noted that blood samples were not collected in the latter studies. After eight weeks of supplementation with large doses of n-3 PUFA per day (4.4g EPA, 2.2g DHA) as an adjunctive therapy [106], depressed patients in the n-3 PUFA group had significantly lower depression scores than the control group $(p<0.001)$. Importantly, this team did collect blood samples and reported average baseline blood DHA levels of $2.5 \%$ of fatty acids in the placebo group and $2.4 \%$ in the treatment group (the latter increased to $5.8 \%$ in the DHA group after treatment). According to the Omega-3 Index for cardiovascular health the baseline levels correspond with the risk category for CVD (EPA + DHA: 4\% of total membrane fatty acids) [11] and are therefore indicative of suboptimal n-3 PUFA levels. There is some recent evidence that $1 \mathrm{~g} /$ day EPA may have similar therapeutic effects to $20 \mathrm{mg}$ /day fluoxetine as a treatment for major depression over eight weeks and that using the two treatments in combination is superior to either of them alone [107]. A larger recent study $(N=120)$ found no improvements in depressive symptoms following $1.5 \mathrm{~g}$ ethyl-EPA plus $0.5 \mathrm{~g}$ ethyl-DHA supplementation in middle-aged women with psychological distress over eight weeks [109], although they reported improvements in women who did not meet criteria for major depressive episode at baseline. A more recent study investigated treatment with $2.2 \mathrm{~g}$ EPA and 1.2g DHA in Menhaden fish oil as a monotherapy for major depressive disorder in pregnant women and found significant improvements in the treatment group on all outcome measures compared with placebo [109]. This study is interesting because n-3 PUFA are preferentially transported to the growing fetus during pregnancy, which can deplete n-3 PUFA levels in pregnant mothers. An uncontrolled study also reported reductions in postpartum depression following n-3 PUFA supplementation over eight weeks [110].

Four studies using DHA or DHA-rich oils did not report improvements following n-3 supplementation. One of these studies supplemented patients with $2 \mathrm{~g}$ DHA for only six weeks as a monotherapy [111]; one supplied 0.6g EPA $+2.4 \mathrm{~g}$ DHA as an adjunctive therapy for 12 weeks [112] and the largest study gave a similar dosage as an adjunctive therapy for 16 weeks [113]. It should be noted though that two of these studies collected blood samples and revealed normal baseline n-3 levels; Marangell et al. [111] reported that the DHA group and placebo group had $4.15 \%$ and 3.78\% DHA as a percentage of total fatty acids at baseline, respectively, and Grenyer et al. [113] reported baseline DHA as $4.2 \%$ of total RBC fatty acids. Although in the latter study reductions in depression scores did not differ between the groups, both treatment and placebo groups had received counseling, which is likely to account for improved mood in the whole sample. Furthermore, these authors later reported that increased DHA levels were significantly associated with improvements in depression scores [114], warranting further research into DHA and depression. Therefore studies using high EPA supplements should also determine to what extent the EPA has been converted to DHA and which of these is associated with improvements.

A larger study investigated depressive symptoms in a cohort of elderly people with mild-moderate Alzheimer's disease who were living in their own homes. This study (cognitive results reported further below) found no benefits of treatment on neuropsychiatric symptoms overall, although improved mood was detected in the treatment group compared with placebo in non apoE-4 allele carriers and reduced agitation in apoE-4 carriers [115]. Given the incidence of depression in Alzheimer's disease, and increased risk of depressed people developing dementia, this merits further investigation. Another 
recently published study investigated additive effects of supplementation with ethyl ester EPA and DHA on depressive symptoms in conjunction with sertraline in patients with major depression and coronary heart disease, finding no benefits of treatment over placebo [116].

In one of two further, larger population based studies, Rogers et al. randomized a community sample of 190 individuals with mild to moderate depression to a combined EPA + DHA supplement (1.5g per day) or olive oil placebo for 12 weeks [117]. They did not report any favourable effects of the supplement on depressive symptoms or a range of outcomes and concluded that this supports a negligible effect of n-3 on depression. A group from the Netherlands also found no effect of n-3 PUFA supplementation on mood in 302 independently living adults [118]. These studies did not use the Hamilton Depression Rating Scales (HDRS), which has been generally used as a primary outcome measure by the other studies, thereby reducing comparability. Although Rogers et al. took blood samples, they measured levels in plasma rather than RBC, and it should be noted that other studies reporting improvements in depression scores tended to use inpatients with more severe depression, many of whom were treatment resistant. Finally, some studies used a placebo lead-in phase to eliminate placebo responders [106], and others used patients who had depression scores indicating impaired function despite ongoing treatment with medication [103]. These selection criteria also could have influenced the outcomes: eliminating placebo responders may be pertinent to clinical trials in depression because often depressive symptoms can lift due to the attention associated with taking part in a clinical trial; non-responders to medication may be a subgroup more likely to respond to n-3 PUFA. Interestingly, Carney et al. did use a two-week placebo lead in phase but did not include nonresponders to medication, and improvements were seen in both treatment and placebo groups, possibly in response to the sertraline administered as an adjunctive therapy [116].

In summary, 13 randomized controlled trials that investigated effects of n-3 PUFA on depressive symptoms were identified, ranging from 4-26 weeks with sample sizes ranging from $N=20-302$, in wide-ranging populations including psychiatric patients, coronary patients, pregnant women, elderly people with Alzheimer's disease and non-depressed community cohorts, one with children, some as adjunctive therapy to existing medication, using variable n-3 PUFA dosages, ratios of EPA:DHA and outcome measures. Five studies reported improvements overall, and two in subgroup analyses. Clearly more studies are needed with larger sample sizes and attention to selection criteria and likely responders, baseline n-3 PUFA levels, erythrocyte blood samples, length of supplementation and comparison of EPA vs. DHA-rich oils. A large number of randomized controlled trials are currently underway around the world investigating n-3 PUFA in depression, including two US studies that are comparing EPA and DHA - see Table 2 for a summary.

\subsection{Bipolar Disorder}

In addition to finding lower DHA levels in the frontal cortex of patients with MDD, McNamara et al. also identified lower DHA levels in the postmortem frontal cortex of 18 patients with bipolar depression compared with 19 age-matched controls [119]. One of the pioneering intervention trials reported on n-3 fatty acids and psychopathology was conducted by Stoll et al. [120] in bipolar disorder patients. The placebo-controlled, double-blind clinical trial produced a significantly greater response to treatment (64\%) in the n-3 PUFA group than in those given olive oil placebos (18.8\%). In this study, 
patients received fish oil capsules containing a total of $6.2 \mathrm{~g}$ EPA and 3.4g DHA daily over four months, with no adverse effects overall. Since then another five studies have been conducted with bipolar patients. An open label study $(N=12)$ provided $1.5-2 \mathrm{~g}$ ethyl EPA for 24 weeks as an adjunctive therapy [121]. Although there was no control group, at one month $7 / 10$ of these previously treatment-resistant patients showed $\geq 50 \%$ reduction in HDRS scores and scores in five completers were dramatically reduced at six months. The other placebo-controlled studies provided ethyl EPA as an adjunctive therapy, supplying 1-2 g for 12 weeks [122] and $6 \mathrm{~g}$ for 16 weeks [123]. Keck et al. reported no improvements in symptoms but Frangou et al. [122] reported significant improvements with $1 \mathrm{~g}$ and $2 \mathrm{~g}$ /day ethyl EPA over placebo in two out of three outcome measures. None of these studies took blood samples.

Frangou et al. [124] also reported increased brain levels of N-acetyl-aspartate (NAA), a presumed marker of neuronal integrity with $2 \mathrm{~g}$ ethyl-EPA in 14 female outpatients compared with placebo, although this was not associated with improvements in symptoms. Treatment with n-3 PUFA in an uncontrolled study with a small group of women with bipolar disorder found no significant improvement over four weeks but also reported alterations in a marker of membrane fluidity in the n-3 groups compared with bipolar patients not taking n-3 PUFA and healthy controls [125]. These alterations in markers of brain function should be explored further, and perhaps in the context of multimodal approaches to treatment.

Depression and bipolar disorder are often associated with suicidal ideation. The relationship between PUFA, increased suicide risk and related disorders is considered in a review by Brunner and colleagues [126], who report an association between low cholesterol and higher risk of suicide. A recent study investigated n-3 PUFA supplementation, in addition to standard psychiatric care, on psychometric measures in adults with recurrent non-fatal self harm [127]. Daily supplementation with n-3 PUFA (1.2 g EPA and 0.9 g DHA) for 12 weeks improved psychopathology, specifically scores for depression, suicidality and daily stresses, compared with placebo in 49 participants.

In summary, two controlled studies have improved bipolar symptoms with a large dose combination of EPA and DHA over four months and 1-2g/day ethyl-EPA over 12 weeks, and there is some evidence from another study that this may impact on suicidal ideation. Again, further investigation of supplement formulation and blood analyses of erythrocyte n-3 PUFAs are needed to investigate relative efficacy of EPA $v s$. DHA vs. a combination of the two. Randomized controlled trials in bipolar depression are currently underway in Germany and the US (see Table 2).

Table 2. Registered (unpublished) double-blind randomized placebo-controlled trials of omega-3 fatty acids in mental illness.*

\begin{tabular}{|l|l|l|l|l|}
\hline Registrant & Country & Title of study & $\begin{array}{l}\text { Date } \\
\text { registered }\end{array}$ & $\begin{array}{l}\text { Registration } \\
\text { number }\end{array}$ \\
\hline $\begin{array}{l}\text { Eric Taylor, Child \& } \\
\text { Adolescent Institute of } \\
\text { Psychiatry }\end{array}$ & UK & $\begin{array}{l}\text { Omega-3 fatty acid supplementation for } \\
\text { adolescent boys with ADHD: a double- } \\
\text { blind, randomized controlled trial } \\
\text { (MAAFA) }\end{array}$ & $09 / 05 / 2006$ & ISRCTN27741572 \\
& & & \\
\hline
\end{tabular}


Table 2. Cont.

\begin{tabular}{|c|c|c|c|c|}
\hline $\begin{array}{l}\text { Natalie Sinn; University } \\
\text { of South Australia \& } \\
\text { Queensland University } \\
\text { of Technology }\end{array}$ & Australia & $\begin{array}{l}\text { Randomized controlled trial investigating } \\
\text { effects of supplementation with omega-3 } \\
\text { fatty acids EPA and DHA versus omega-6 } \\
\text { fatty acid LA on ADHD symptoms and } \\
\text { learning difficulties in 7-12 year old } \\
\text { children }\end{array}$ & $20 / 06 / 2007$ & $\begin{array}{l}\text { ACTRN } \\
012607000332426\end{array}$ \\
\hline $\begin{array}{l}\text { Madeleine Portwood; } \\
\text { Durham County Council }\end{array}$ & UK & $\begin{array}{l}\text { The Middlesbrough study: A randomized, } \\
\text { controlled trial of dietary supplements } \\
\text { with omega-3/omega- } 6 \text { fatty acids in } \\
\text { mainstream school children }\end{array}$ & $28 / 09 / 2007$ & ISRCTN12286781 \\
\hline Laboratories URGO & France & $\begin{array}{l}\text { A randomized, controlled, double blind } \\
\text { placebo trial to evaluate the efficacy and } \\
\text { the tolerance of an omega- } 3 \text { fatty acids } \\
\text { supplement in ADHD children }\end{array}$ & 09/10/2008 & NCT00770627 \\
\hline $\begin{array}{l}\text { Hadassah Medical } \\
\text { Organisation }\end{array}$ & Israel & $\begin{array}{l}\text { The effect of omega- } 3 \text { fatty acid } \\
\text { supplementation on behavior of children } \\
\text { with ADHD }\end{array}$ & 01/04/2009 & NCT00874536 \\
\hline $\begin{array}{l}\text { Sherie Novotny; New } \\
\text { Jersey University of } \\
\text { Medicine and Dentistry }\end{array}$ & USA & $\begin{array}{l}\text { Omega- } 3 \text { fatty acids in the treatment of } \\
\text { children with autism spectrum disorders }\end{array}$ & $27 / 04 / 2007$ & NCT00467818 \\
\hline $\begin{array}{l}\text { Stephen Bent; University } \\
\text { of California }\end{array}$ & USA & $\begin{array}{l}\text { A randomized, double-blind, placebo- } \\
\text { controlled 12-week study to investigate } \\
\text { the effect of omega-3 fatty acids on } \\
\text { hyperactivity in childhood autism }\end{array}$ & $05 / 11 / 2008$ & NCT00786799 \\
\hline $\begin{array}{l}\text { Atul Singhal, Institute of } \\
\text { Child Health }\end{array}$ & UK & $\begin{array}{l}\text { The influence of n-3 fatty acid } \\
\text { supplementation on vascular and cognitive } \\
\text { function in healthy young adults; a } \\
\text { randomized controlled trial }\end{array}$ & $05 / 05 / 2005$ & ISRCTN19987575 \\
\hline $\begin{array}{l}\text { Lev Gertsik; National } \\
\text { Center for } \\
\text { Complementary and } \\
\text { Alternative Medicine }\end{array}$ & USA & $\begin{array}{l}\text { PUFA augmentation in treatment of major } \\
\text { depression }\end{array}$ & $14 / 08 / 2003$ & NCT00067301 \\
\hline $\begin{array}{l}\text { Maria Makrides; Child } \\
\text { Nutrition Research } \\
\text { Centre }\end{array}$ & Australia & $\begin{array}{l}\text { A randomized trial of DHA in pregnancy } \\
\text { to prevent postnatal depressive symptoms } \\
\text { and enhance neurodevelopment in } \\
\text { children: The DOMInO Trial }\end{array}$ & $30 / 09 / 2005$ & $\begin{array}{l}\text { ACTRN } \\
12605000569606\end{array}$ \\
\hline $\begin{array}{l}\text { Anne Marie Rees; } \\
\text { University of New South } \\
\text { Wales }\end{array}$ & Australia & $\begin{array}{l}\text { A randomized, double-blind, placebo } \\
\text { controlled trial of omega- } 3 \\
\text { polyunsaturated fatty acids as a } \\
\text { monotherapy for major depression }\end{array}$ & $11 / 10 / 2005$ & NCT00238758 \\
\hline $\begin{array}{l}\text { William Coryell; } \\
\text { University of Iowa }\end{array}$ & USA & $\begin{array}{l}\text { Essential fatty acids in management of } \\
\text { major depressive Disorder - A pilot study }\end{array}$ & $16 / 11 / 2005$ & NCT00256412 \\
\hline
\end{tabular}


Table 2. Cont.

\begin{tabular}{|c|c|c|c|c|}
\hline $\begin{array}{l}\text { F Pouwer; VU } \\
\text { University Medical } \\
\text { Centre, EMGO-Institute }\end{array}$ & Netherlands & $\begin{array}{l}\text { Addition of eicosapentaenoic acid to } \\
\text { maintenance anti-depressant therapy in } \\
\text { diabetes patients with major depressive } \\
\text { disorder: a double-blind, placebo- } \\
\text { controlled study }\end{array}$ & $21 / 03 / 2006$ & $\begin{array}{l}\text { NTR624; } \\
\text { ISRCTN30877831 }\end{array}$ \\
\hline $\begin{array}{l}\text { Gordon Parker; } \\
\text { University of New South } \\
\text { Wales }\end{array}$ & Australia & $\begin{array}{l}\text { A randomized, double-blind, placebo } \\
\text { controlled trial of omega-3 } \\
\text { polyunsaturated fatty acid as an augmenter } \\
\text { of antidepressant medication for major } \\
\text { depression }\end{array}$ & $07 / 02 / 2006$ & NCT00289484 \\
\hline $\begin{array}{l}\text { Vilma Gabbay; National } \\
\text { Centre for } \\
\text { Complementary and } \\
\text { Alternative Medicine }\end{array}$ & USA & $\begin{array}{l}\text { Omega-3 fatty acids in adolescent } \\
\text { depression }\end{array}$ & 07/04/2006 & NCT00312897 \\
\hline $\begin{array}{l}\text { David Mischoulon; } \\
\text { Massachusetts General } \\
\text { Hospital }\end{array}$ & USA & $\begin{array}{l}\text { Omega-3 fatty acids for treatment of major } \\
\text { depression: Differential effects of EPA } \\
\text { and DHA, and associated biochemical and } \\
\text { immune parameters }\end{array}$ & $04 / 08 / 2006$ & NCT00361374 \\
\hline $\begin{array}{l}\text { Elad Schiff; Bnai Zion } \\
\text { Medical Center }\end{array}$ & Israel & $\begin{array}{l}\text { Prevention of depression with omega-3 } \\
\text { fatty acids in chronic carriers of hepatitis } \\
\text { C treated with interferon alpha }\end{array}$ & $05 / 12 / 2006$ & NCT00408304 \\
\hline $\begin{array}{l}\text { Robert McNamara; } \\
\text { University of Cincinnati }\end{array}$ & USA & $\begin{array}{l}\text { Evaluation of omega- } 3 \text { fatty acids as a } \\
\text { treatment-adjunct in adolescent patients } \\
\text { with major depressive disorder exhibiting } \\
\text { partial response to SSRI medication: an } \\
\text { open-label neuroimaging trial }{ }^{\text {a }}\end{array}$ & $03 / 08 / 2007$ & NCT00511810 \\
\hline $\begin{array}{l}\text { Danit Shahar; Beersheva } \\
\text { Mental Health Center }\end{array}$ & Israel & $\begin{array}{l}\text { Folic acid and omega- } 3 \text { fatty acid } \\
\text { supplementation in depressed older adults } \\
\text { - factorial assignment }\end{array}$ & $28 / 05 / 2007$ & NCT00480207 \\
\hline $\begin{array}{l}\text { Mark Rapaport; National } \\
\text { Institute of Mental } \\
\text { Health (NIMH) }\end{array}$ & USA & $\begin{array}{l}\text { Omega-3 fatty acids for treatment of major } \\
\text { depression: Differential effects of EPA } \\
\text { and DHA, and associated biochemical and } \\
\text { immune parameters }\end{array}$ & $14 / 08 / 2007$ & NCT00517036 \\
\hline $\begin{array}{l}\text { Matthew Muldoon; } \\
\text { University of Pittsburgh }\end{array}$ & USA & $\begin{array}{l}\text { Evaluating the effects of omega- } 3 \text { fatty } \\
\text { acids on heart disease and behavior; } \\
\text { Biobehavioral studies of cardiovascular } \\
\text { disease }\end{array}$ & $18 / 04 / 2008$ & NCT00663871 \\
\hline $\begin{array}{l}\text { Sayed Naqvi; Cedars- } \\
\text { Sinai Medical Centre }\end{array}$ & USA & $\begin{array}{l}\text { Omega- } 3 \text { fatty acids for treatment of } \\
\text { depression in adolescents }\end{array}$ & $08 / 04 / 2008$ & NCT00658476 \\
\hline
\end{tabular}


Table 2. Cont.

\begin{tabular}{|c|c|c|c|c|}
\hline $\begin{array}{l}\text { Alexandra Parker; } \\
\text { Orygen Youth Health - } \\
\text { Research Centre }\end{array}$ & Australia & $\begin{array}{l}\text { The acceptability and effectiveness of a } \\
\text { combination of problem solving therapy, } \\
\text { behavioral exercise intervention and } \\
\text { omega-3 supplements compared to a } \\
\text { combination of supportive counseling, } \\
\text { exercise psychoeducation, and placebo } \\
\text { omega-3 in reducing depression and } \\
\text { anxiety symptoms in help-seeking young } \\
\text { people aged } 12-25 \text { years: A factorial } \\
\text { randomized controlled trial }\end{array}$ & $30 / 10 / 2008$ & $\begin{array}{l}\text { ACTRN } \\
12608000550303\end{array}$ \\
\hline $\begin{array}{l}\text { Geoffrey Schrader, } \\
\text { Queen Elizabeth } \\
\text { Hospital; Peter Howe, } \\
\text { University of South } \\
\text { Australia }\end{array}$ & Australia & $\begin{array}{l}\text { Omega-3 fatty acid supplementation for } \\
\text { symptoms of depression in patients with } \\
\text { cardiovascular disease }\end{array}$ & $01 / 12 / 2008$ & $\begin{array}{l}\text { ACTRN } \\
12608000598381\end{array}$ \\
\hline $\begin{array}{l}\text { National Science } \\
\text { Council }\end{array}$ & Taiwan & $\begin{array}{l}\text { The effect of fish oil in major depressive } \\
\text { disorder: a double-blind placebo- } \\
\text { controlled monotherapy trial to } \\
\text { demonstrate the therapeutic and preventive } \\
\text { effects of [sic]depression }\end{array}$ & $31 / 12 / 2008$ & NCT00816322 \\
\hline $\begin{array}{l}\text { Vlima Gabbay; NYU } \\
\text { School of Medicine }\end{array}$ & USA & $\begin{array}{l}\text { The role of omega- } 3 \text { fatty acids in } \\
\text { adolescent depression }\end{array}$ & $19 / 08 / 2009$ & NCT00962598 \\
\hline $\begin{array}{l}\text { Krista Lanctôt; } \\
\text { Sunnybrook Health } \\
\text { Sciences Centre } \\
\end{array}$ & Canada & $\begin{array}{l}\text { Treating depression in coronary artery } \\
\text { disease with omega- } 3 \text { fatty acids } \\
\text { (CAROTID) }\end{array}$ & $10 / 09 / 2009$ & NCT00981383 \\
\hline $\begin{array}{l}\text { National Institute of } \\
\text { Mental Health (NIMH) }\end{array}$ & USA & $\begin{array}{l}\text { Omega-3 fatty acids in the treatment of } \\
\text { major depression and bipolar disorder: A } \\
\text { double-blind, placebo-controlled trial }\end{array}$ & $\begin{array}{l}\text { 03/11/1999 } \\
\text { (estimated } \\
\text { completion } \\
2002) \\
\end{array}$ & NCT00001146 \\
\hline $\begin{array}{l}\text { Andrew Stoll; National } \\
\text { Center for } \\
\text { Complementary and } \\
\text { Alternative Medicine }\end{array}$ & USA & $\begin{array}{l}\text { Omega- } 3 \text { fatty acids in bipolar disorder } \\
\text { prophylaxis }\end{array}$ & \begin{tabular}{|l|}
$02 / 02 / 2001$ \\
(estimated \\
completion \\
$2004)$ \\
\end{tabular} & NCT00010868 \\
\hline $\begin{array}{l}\text { Barbara Gracious; } \\
\text { University of Rochester }\end{array}$ & USA & $\begin{array}{l}\text { A comparison of omega-3 fatty acids } v s \text {. } \\
\text { placebo in children and adolescents with } \\
\text { bipolar disorder }\end{array}$ & $09 / 11 / 2005$ & NCT00252486 \\
\hline $\begin{array}{l}\text { Janet Wozniak; } \\
\text { Massachusetts General } \\
\text { Hospital }\end{array}$ & USA & $\begin{array}{l}\text { A randomized placebo controlled clinical } \\
\text { trial of omega-3 fatty acid adjunctive to } \\
\text { open-label aripiprazole for the treatment } \\
\text { of bipolar disorder in children and } \\
\text { adolescents ages 6-17 with bipolar } \\
\text { spectrum disorder }\end{array}$ & $28 / 12 / 2007$ & NCT00592683 \\
\hline
\end{tabular}


Table 2. Cont.

\begin{tabular}{|c|c|c|c|c|}
\hline $\begin{array}{l}\text { Sencan Unal; Mayo } \\
\text { Clinic }\end{array}$ & USA & $\begin{array}{l}\text { Neurometabolic effects of the essential } \\
\text { polyunsaturated fatty acids in early-onset } \\
\text { bipolar disorder: A magnetic resonance } \\
\text { spectroscopy study }\end{array}$ & $21 / 12 / 2007$ & NCT00586222 \\
\hline $\begin{array}{l}\text { Emanuel Severus; } \\
\text { University of Munich }\end{array}$ & Germany & $\begin{array}{l}\text { Omega- } 3 \text { fatty acids in bipolar patients } \\
\text { with a low omega-3 index and reduced } \\
\text { heart rate variability: The BIPO- } 3 \text { Trial }\end{array}$ & $28 / 04 / 2009$ & NCT00891826 \\
\hline $\begin{array}{l}\text { Beth Murphy; Mclean } \\
\text { Hospital }\end{array}$ & USA & $\begin{array}{l}\text { A combination of cytidine and omega-3 } \\
\text { fatty acids in bipolar disorder: Are there } \\
\text { additive or synergistic mood stabilizing } \\
\text { effects? }\end{array}$ & $27 / 02 / 2009$ & NCT00854737 \\
\hline $\begin{array}{l}\text { Melissa DelBello, } \\
\text { Robert McNamara; } \\
\text { University of Cincinnati }\end{array}$ & USA & $\begin{array}{l}\text { Neurochemical effects of omega- } 3 \text { fatty } \\
\text { acids in adolescents at risk for mania }\end{array}$ & 08/06/2009 & NCT00917501 \\
\hline $\begin{array}{l}\text { Jeffrey Yao; University } \\
\text { of Pittsburgh }\end{array}$ & USA & $\begin{array}{l}\text { Coronary artery disease risk in } \\
\text { schizophrenia: Effect of omega-3 fatty } \\
\text { acid supplementation }\end{array}$ & $09 / 09 / 2005$ & NCT00167310 \\
\hline $\begin{array}{l}\text { Havard Bentsen; } \\
\text { University Hospital, } \\
\text { Aker }\end{array}$ & Norway & $\begin{array}{l}\text { A multicentre, placebo-controlled trial of } \\
\text { eicosapentaenoic acid (EPA) and } \\
\text { antioxidant supplementation in the } \\
\text { treatment of schizophrenia and related } \\
\text { disorders }\end{array}$ & $05 / 01 / 2007$ & NCT00419146 \\
\hline $\begin{array}{l}\text { Neil Richtand; } \\
\text { University of Cincinnati }\end{array}$ & USA & $\begin{array}{l}\text { Randomized, double-blind, placebo- } \\
\text { controlled pilot trial of essential fatty acid } \\
\text { deficiency replacement in early } \\
\text { schizophrenia }\end{array}$ & $28 / 12 / 2007$ & NCT00585390 \\
\hline $\begin{array}{l}\text { Paul Amminger, Patrick } \\
\text { McGorry; Orygen } \\
\text { Research Centre }\end{array}$ & $\begin{array}{l}\text { Australia, } \\
\text { Austria, } \\
\text { China, } \\
\text { Denmark, } \\
\text { Germany, } \\
\text { Switzerland, } \\
\text { UK }\end{array}$ & $\begin{array}{l}\text { The NEURAPRO-E (North America, } \\
\text { EURope, Australia PROdrome) Study: A } \\
\text { multicenter randomized controlled trial of } \\
\text { omega-3 fatty acids and cognitive- } \\
\text { behavioral case management for } \\
\text { symptomatic patients at ultra-high risk for } \\
\text { early progression to schizophrenia and } \\
\text { other psychotic disorders to assess the 6- } \\
\text { month transition rate to first episode } \\
\text { psychosis }\end{array}$ & $23 / 09 / 2008$ & $\begin{array}{l}\text { ACTRN } \\
12608000475347\end{array}$ \\
\hline $\begin{array}{l}\text { Laure Buydens- } \\
\text { Branchey; National } \\
\text { Institute on Drug Abuse } \\
\text { (NIDA) }\end{array}$ & USA & $\begin{array}{l}\text { Effects of fatty acid supplementation on } \\
\text { substance dependent individuals }\end{array}$ & $06 / 04 / 2006$ & NCT00312455 \\
\hline $\begin{array}{l}\text { Miquel Casas; Hospital } \\
\text { Universitari Vall } \\
\text { d'Hebron Research } \\
\text { Institute }\end{array}$ & Spain & $\begin{array}{l}\text { Efficacy of omega-3 fatty acids on } \\
\text { borderline personality disorder: A } \\
\text { randomized, double-blind clinical trial }\end{array}$ & $16 / 02 / 2007$ & NCT00437099 \\
\hline
\end{tabular}


Table 2. Cont.

\begin{tabular}{|c|c|c|c|c|}
\hline $\begin{array}{l}\text { John Stein; University of } \\
\text { Oxford }\end{array}$ & UK & $\begin{array}{l}\text { Nutrition as a modifiable causal factor in } \\
\text { anti-social behaviors: A randomized, } \\
\text { placebo controlled, double blind trial } \\
\text { (PINUP - PrIson NUtrition Project) }\end{array}$ & $06 / 01 / 2009$ & ISRCTN41104834 \\
\hline $\begin{array}{l}\text { Joanne Bradbury; } \\
\text { Blackmores Ltd, } \\
\text { Southern Cross } \\
\text { University }\end{array}$ & Australia & $\begin{array}{l}\text { A pilot randomized controlled double } \\
\text { blind intervention study of the effects of } \\
\text { docosahexaenoic acid (DHA)-rich fish oil } \\
\text { compared with olive oil in psychological } \\
\text { stress }\end{array}$ & $20 / 02 / 2009$ & $\begin{array}{l}\text { ACTRN } \\
12609000124235\end{array}$ \\
\hline $\begin{array}{l}\text { Alan Dangour, Medical } \\
\text { Research Council (UK) } \\
{[179]}\end{array}$ & UK & $\begin{array}{l}\text { The OPAL Study: Older People And n-3 } \\
\text { Long-chain polyunsaturated fatty acids } \\
\text { (target sample: } 800 \text { people) }\end{array}$ & $14 / 07 / 2004$ & ISRCTN72331636 \\
\hline $\begin{array}{l}\text { Janet Carter; Department } \\
\text { of Health; North East } \\
\text { London Mental Health } \\
\text { Trust }\end{array}$ & UK & $\begin{array}{l}\text { A randomized placebo-controlled trial of } \\
\text { polyunsaturated omega- } 3 \text { fatty acid in the } \\
\text { treatment of dementia; a pilot study }\end{array}$ & $30 / 09 / 2005$ & ISRCTN27372325 \\
\hline $\begin{array}{l}\text { Joseph Quinn; National } \\
\text { Institute on Aging }\end{array}$ & USA & $\begin{array}{l}\text { A randomized double-blind placebo- } \\
\text { controlled trial of the effects of } \\
\text { docosahexaenoic acid (DHA) in slowing } \\
\text { the progression of Azheimer's Disease }\end{array}$ & $22 / 02 / 2007$ & NCT00440050 \\
\hline $\begin{array}{l}\text { Vanessa Danthiir; } \\
\text { Commonwealth } \\
\text { Scientific Industrial } \\
\text { Research Organisation } \\
\text { (CSIRO) }\end{array}$ & Australia & $\begin{array}{l}\text { An } 18 \text { month study investigating the } \\
\text { effects of long chain omega-3 } \\
\text { polyunsaturated fatty acids } \\
\text { supplementation on cognition and } \\
\text { wellbeing in older people (EPOCH) }\end{array}$ & $24 / 05 / 2007$ & $\begin{array}{l}\text { ACTRN } \\
12607000278437\end{array}$ \\
\hline $\begin{array}{l}\text { Bruno Vellas; Toulouse } \\
\text { University Hospital } \\
{[180]}\end{array}$ & France & $\begin{array}{l}\text { Assessment of the efficacy of omega-3 } \\
\text { fatty acids supplementation, multi-domain } \\
\text { intervention or their combination on the } \\
\text { change of cognitive functions in frail } \\
\text { elderly subjects }\end{array}$ & $02 / 05 / 2008$ & NCT00672685 \\
\hline $\begin{array}{l}\text { Natalie Sinn; University } \\
\text { of South Australia }\end{array}$ & Australia & $\begin{array}{l}\text { Effects of omega- } 3 \text { fatty acids high in } \\
\text { eicosapentaenoic acid (EPA) or } \\
\text { docosahexaenoic acid (DHA) versus } \\
\text { placebo on cognition and mood in older } \\
\text { adults with mild cognitive impairment }\end{array}$ & 03/04/2009 & $\begin{array}{l}\text { ACTRN } \\
12609000167268\end{array}$ \\
\hline $\begin{array}{l}\text { Katia Tanaka; } \\
\text { Universidade Federal de } \\
\text { Sao Paulo }\end{array}$ & Brazil & $\begin{array}{l}\text { A randomized controlled trial evaluating } \\
\text { the effects of the association of ginkgo } \\
\text { biloba, omega-3 and physical exercise in } \\
\text { memory and executive functions of older } \\
\text { people with Parkinson's disease }\end{array}$ & $22 / 07 / 2009$ & $\begin{array}{l}\text { ACTRN } \\
12609000609257\end{array}$ \\
\hline $\begin{array}{l}\text { Christine Marx, Durham } \\
\text { VA Medical Centre }\end{array}$ & USA & $\begin{array}{l}\text { Omega- } 3 \text { fatty acids and post traumatic } \\
\text { stress disorder }\end{array}$ & $20 / 03 / 2008$ & NCT00644423 \\
\hline
\end{tabular}


Table 2. Cont.

\begin{tabular}{|l|l|l|l|l|}
\hline $\begin{array}{l}\text { Yutaka Mastuoka; Japan } \\
\text { Science and Technology } \\
\text { Agency }\end{array}$ & Japan & $\begin{array}{l}\text { Phase 2 study of Tachikawa Project for } \\
\text { Prevention of Post-traumatic stress } \\
\text { disorder with polyunsaturated fatty acid: } \\
\text { TPOP-01 Study }\end{array}$ & $23 / 04 / 2008$ & NCT00671489 \\
\hline $\begin{array}{l}\text { Yutaka Mastuoka; Japan } \\
\text { Science and Technology } \\
\text { Agency }\end{array}$ & Japan & $\begin{array}{l}\text { Tachikawa Project for Prevention of Post- } \\
\text { traumatic stress disorder with } \\
\text { polyunsaturated fatty acid: TPOP-02 } \\
\text { Study }\end{array}$ & $01 / 05 / 2008$ & NCT00671099 \\
\hline
\end{tabular}

Trials are grouped according to subheadings in main text (e.g., ADHD, depression, etc.), apart from three new studies in post-traumatic stress disorder. All trial identification numbers were searched in PubMed to check if they had been published yet. *Located on the World Health Organization's International Clinical Trials Registry Platform Search Portal (http://apps.who.int/trialsearch/)-search terms 'omega-3' or ' $n-3$ fatty acids'. 'This trial was open label and uncontrolled but was included in the table because of physiological assessment of neurological changes in response to omega-3 supplementation

\subsection{Schizophrenia}

There are a number of indications that phospholipid abnormalities may explain biological underpinnings of schizophrenia [26,128-131]. Low n-3 fatty acid levels in diets or RBC have consistently been found in people with schizophrenic symptoms compared to controls [132-136]. Clinical trials with schizophrenia have reported mostly positive results. In an apparently open-label trial with 20 schizophrenic patients, significant improvements in symptoms were reported after daily supplementation with $10 \mathrm{~g}$ fish oil over six weeks, and improvements were reported to correlate with increased n-3 PUFA blood levels [137]. Four double-blind controlled trials with EPA supplementation have produced some significant, positive outcomes [138-140] although in Peet et al. 2002 [140] only with $2 \mathrm{~g}$ ( $v s$. 1 and $4 \mathrm{~g}$ ) ethyl-EPA per day in the subgroup of patients taking clozapine and improvements were also associated with increased levels of AA.

Another trial found no differences between schizophrenic patients given ethyl EPA and those given placebo over 16 weeks [141]. Horrobin [142] proposed a number of reasons why an effect might not have been obtained, including the possibility that ethyl EPA may not have therapeutic benefits. Hibbeln et al. [143] investigated possible confounding variables using the same data set, and found that PUFA status in schizophrenic patients was predicted by smoking status, gender, and dietary intake of n-3 fatty acids. They concluded that phospholipid abnormalities may be an artefact of these variables. However, Emsley et al. [138] found significant differences between active and placebo groups on the Positive and Negative Syndrome Scale after controlling for age, gender, length of illness and dietary n-3 intake; further analyses revealed that these improvements were accounted for by improved dyskinesia.

In another recent study [132], schizophrenic patients were matched with healthy controls on a number of factors known to influence PUFA status including age, gender, dietary patterns, smoking 
and substance abuse. Schizophrenic patients still had significantly lower levels of EPA and DHA, and higher levels of AA than controls. They then gave patients in their study a combination of EPA, DHA and antioxidants (Vitamins $\mathrm{E}$ and $\mathrm{C}$ ) over four months; there was no placebo group. The researchers reported significant within-group improvements on various measures of psychopathology between preand post-treatment, which continued for four months after the treatment was discontinued. These results need to be interpreted with caution given equivalent placebo to treatment effects found in other trials of both depression and schizophrenia. Two more recently published studies focused on firstepisode psychosis. The first study was with young adults who were provided $2 \mathrm{~g}$ /day of ethyl-EPA or placebo along with psychotic medication (the majority had been previously unmedicated) [144]. Initial analyses found no treatment effects over 12 weeks; however did find improvements in patients with non-affective psychosis and in those who had had longer duration of untreated psychosis. Treatment effects were significant at 4-6 weeks then matched the placebo group at 12 weeks, indicating that the ethyl-EPA may have improved response to psychotic medication and/or the effects of the medication matched the ethyl-EPA by 12 weeks. The second study aimed to investigate whether $1.3 \mathrm{~g} / \mathrm{day} \mathrm{n}-3$ PUFA supplementation over 12 weeks could reduce the transition of sub-threshold psychosis to firstepisode psychotic disorder in adolescents and young adults over 12 months [145]. There was a significantly reduced transition to psychosis in the treatment group (2/41) compared with the placebo group (11/40). A couple of further trials in schizophrenia, one a multicentre intervention involving the latter research group, are currently underway (see Table 2).

\subsection{Stress, Aggression, Hostility, Impulsivity, Criminal and Antisocial Behavior}

A number of studies have indicated a biological basis for aggression and criminal-related behaviour. Low concentrations of cerebrospinal fluid 5-hydroxyindoleacetic acid (CSF 5-HIAA), a marker of cerebral serotonin turnover, have consistently been associated with impulsive, violent, suicidal, hostile and aggressive behaviors, as well as early onset of alcohol dependence and personality disorders $[31,146]$. Low PUFA status has also been associated with deficient serotonergic neurotransmission $[28,29]$ and it is possible that low CSF 5-HIAA reflects this deficiency.

A small number of clinical trials have investigated the impact of PUFA supplementation on aggressive behaviour. A double-blind, placebo-controlled study measured effects of daily supplementation with oil containing 49.3\% (1.5g) DHA, 6.7\% EPA, 7.3\% oleic acid, 3.3\% AA and other oils for three months on cognitive outcomes and aggression in a group of 41 healthy Japanese students from two universities [147]. The placebo capsules contained small amounts of LA and ALA. No differences between groups were observed on cognitive tests of executive function, but a significant difference was reported in aggression towards others ('extraggression') at the end of the study, during a highly stressful final exam period. Extraggression scores significantly increased in the control groups and decreased (though not significantly) in the DHA supplemented groups. Serum blood analyses confirmed a significant increase in EPA and DHA levels in the treatment groups. Therefore three months' supplementation with n-3 PUFA seemed to assist students in controlling aggression towards others on a psychological test during a period of high stress. Drawing from research on stress-induced hostility and aggression, an Australian group investigated a possible 
adaptive role of DHA in perceived stress levels of university staff, finding no differences between treatment and placebo but positive effects in the treatment compared with a control group [148].

Another double-blind study tested effects of supplementation with $1 \mathrm{~g}$ ethyl-EPA daily or placebo over eight weeks on moderate borderline personality disorder, characterized by emotional reactivity and impulsive aggression, in a group of women [149]. The treatment group had a significantly greater decrease in depression and aggression scores at the end of the study.

A landmark randomized, placebo-controlled trial was undertaken with 231 young adult prisoners to investigate effects of supplementation with micronutrients and essential fatty acids over four-five months on antisocial behavior [150]. The participants were given multi-vitamin/mineral capsules and fatty acid supplement providing n-3 and n-6 fatty acids (1260mg LA, 160mg GLA, 80mg EPA and $44 \mathrm{mg}$ DHA daily) or placebo. During the trial, the treatment group received significantly fewer disciplinary actions, and the greatest effect was noted for violent behavior. These studies add an important dimension to research with PUFA in ADHD, which is commonly associated with antisocial behavior symptomatic of conduct disorder and oppositional defiant disorder in childhood [151-153] and criminality and antisocial behavior in late adolescence and adulthood [154,155]. This work is currently being continued on a large scale with prisons in the UK, investigating effects of micronutrients and PUFA on anti-social behaviour in a randomized controlled trial over 4 months ('PINUP'; see Table 2).

Recently, a small randomized controlled trial in 24 men with substance abuse found that supplementation with 3g/day of n-3 PUFAs for three months improved self-reported scores of anger and anxiety compared to a soybean oil placebo [156]. The active group received five capsules per day each containing $450 \mathrm{mg}$ of EPA, $100 \mathrm{mg}$ of DHA and $50 \mathrm{mg}$ of n-3 PUFAs ALA and DPA. Although five participants in both the placebo and active groups were on antidepressant medication during the study, their doses remained stable. Interestingly, the anger ratings remained lower in the active group for three months after supplementation ceased. Each participant's n-3 PUFA intake was calculated from a diet questionnaire covering the month preceding the study and it was reported that the participants had a daily intake of $148 \mathrm{mg}$ LC n-3 PUFAs, only $30 \%$ of the ISSFAL recommended intake of $500 \mathrm{mg} /$ day. Furthermore, those participants who reported a history of violent behaviour had a significantly lower LC n-3 PUFA intake compared to those who had no history of this behaviour. After the 3 month treatment with LC n-3 PUFAs, a low anxiety score was associated with an increase in EPA but not DHA, whereas a low anger score was associated more strongly with DHA. This indicates possible variation between the two LC n-3 PUFAs in their effect on psychiatric conditions and warrants comparison of them in further research.

A randomized controlled trial is currently investigating the role of n-3 PUFA in alleviating psychological stress in university students undertaking exams, and another study in Spain is assessing n-3 PUFA supplementation for symptoms of borderline personality disorder (Table 2).

\subsection{Dementia and Alzheimer's Disease}

Free radical activity and phospholipid membrane degeneration have been associated with neurodegenerative disorders. With aging, neural membrane fluidity is generally compromised due to an increase in cholesterol, reduced activity level of desaturase enzymes, impaired phospholipid 
metabolism and increased oxidative stress [20]. Such derangements may be associated with dementia and Alzheimer's Disease (AD), e.g., autopsied brains of patients who suffered AD showed significantly higher saturated fat and lower PUFA content, particularly DHA, in the hippocampus and frontal lobes compared to aged controls [157], which is consistent with reports of decreased hippocampus size and function in AD patients [20].

Prospective cohort/population studies have indicated that higher fish consumption is associated with reduced risk of dementia/AD [158-165]. A single case report of an elderly dementia patient noted clinical improvement over several months of increased fish consumption, which led the author to hypothesise that n-3 PUFA contributed to his improved functioning, although it could have been attributed to numerous other factors associated with admittance to a nursing home [166]. Investigation of n-3 PUFA status in AD patients did find significantly reduced EPA and DHA levels compared to controls, particularly DHA levels which were consistently less than half those in the control group [167].

Relatively few controlled studies have investigated effects of n-3 PUFA supplementation on dementia to date. In a short four-week double blind trial with $100 \mathrm{AD}$ patients, a number of improvements in symptoms were reported in 49 of the 60 patients who received an n-3/n- 6 supplement comprising $0.5 \mathrm{~g}$ of ALA and LA in a 1:4 ratio [168].

Supplementation with $4.32 \mathrm{~g}$ DHA daily for one year improved dementia scores of 10 elderly volunteers with vascular dementia compared with 10 controls who did not receive capsules [169]. Another pilot study in 19 participants with mild to moderate AD treated with 1g/day ethyl-EPA for 12 weeks showed no improvement in cognitive functioning, possibly due to the short period of supplementation and/or the nature of the supplement formulation [170]. Supplementation with $240 \mathrm{mg} /$ day of DHA and AA improved immediate memory and attention in 12 adults with mild cognitive impairment (MCI) but not eight adults with AD compared to an olive oil MCI placebo group [171]. In the largest study to date with 174 volunteers with diagnosed AD, only those with very mild AD $(n=27)$ showed reductions in cognitive decline after adjunctive supplementation with 1700 $\mathrm{mg}$ /day DHA and $600 \mathrm{mg}$ /day EPA for six months and the placebo group improved after switching to n-3 PUFA for a further 6 months [172]. Similarly, a study recently published online also reported improvements relative to placebo in MCI but not AD patients following supplementation with 1.8g/day n-3 PUFA (1080mg EPA, 720mg DHA) over 24 weeks [173]. One population based study investigated the effect of DHA and EPA on cognitive performance of 302 elderly people $>65$ years without dementia and detected no treatment effects over 26 weeks, although it did report improvements in attention in apoE-4 carriers and males [174]. The prior studies indicate that early stages of cognitive decline may be optimal for intervention with n-3 PUFA. MCI is considered a risk factor for $\mathrm{AD}$, with an estimated $16-41 \%$ of people with $\mathrm{MCI}$ converting to a diagnosis of $\mathrm{AD}$ each year and up to $64 \%$ after two years. It has been suggested therefore that MCI is possibly the earliest stage of detectable AD [175]. Furthermore, major and minor depression often co-occur in MCI [176] and increase the risk of progressing to AD [177].

Further investigation of the role of PUFA in dementia is needed, focusing on larger sample sizes, the nature of the supplement (e.g., EPA versus DHA), dosage, length of supplementation, baseline RBC n-3 PUFA proportions, response in ApoE $\varepsilon 4$ allele carriers, longer-term outcomes and 
therapeutic implications. Finally, cardiovascular risk factors for AD have led to recent suggestions that lifestyle factors such as inadequate physical activity and/or n-3 PUFA intake may contribute to reduced cerebral blood flow and blood-brain barrier integrity [37], supporting the notion that one of the primary functions of n-3 PUFA on mental health may be improved circulatory function [36]. This should also be explored in future research.

We are currently collecting data for a six-month study comparing EPA with DHA-rich supplements versus an LA placebo on mood and cognition in elderly people with MCI. Other controlled trials are underway to assess n-3 PUFA supplementation and cognition in healthy older adults and those with dementia (see Table 2 for details).

\section{Conclusions}

There is growing evidence that suboptimal intakes of n-3 PUFA may be associated with psychopathology over the lifespan and include highly prevalent disorders that present a growing public health concern. Most clinical trials have been conducted with major depressive illness in adulthood and in childhood disorders; there are growing numbers of interventions with cognitive decline in older adulthood. Although the causes of these mental health problems are complex and multifactorial, even from a nutritional perspective alone [e.g., 40, 178], dietary and lifestyle factors including n-3 PUFA present modifiable risk factors that can be accessed relatively easily by individuals.

However, findings of clinical trials have been inconsistent and in many cases inconclusive; methodological differences between studies need to be critically evaluated before drawing conclusions about the efficacy or otherwise of n-3 PUFA in alleviating symptoms. These include sample size, selection criteria, the dosage of the supplement, the nature of the fatty acids (i.e. EPA- or DHA-rich or combined oil; inclusion of n-6 PUFA), and length of supplementation. Given the widespread use of ethyl-esthers, short- and long-term investigation of bioavailability compared with naturally occurring fatty acids in fish oil is warranted. The role of n-6 PUFA also needs to be clarified as some studies found improved and some worse outcomes associated with AA, and successful studies with children included evening primrose oil in the treatment. Some studies in depression have included inpatients with clinical depression despite ongoing medication. Non-responders to other treatments are a possible future area of attention for n-3 PUFA and/or micronutrient supplementation because suboptimal nutrient levels may explain this lack of response to other treatments. Some depression studies have conducted a placebo-lead in phase to eliminate placebo responders and this may also assist in clarifying true treatment effects. Importantly, studies need to identify baseline n-3 PUFA levels in erythrocyte membranes because this may be a major contributor to different findings between studies. This will also assist researchers and clinicians in identifying likely responders.

Outcome measures also need consideration; as can be seen in Table 1, a great variety of psychological/cognitive outcome measures have been used across these studies and their sensitivity to detecting effects of n-3 PUFA supplementation is varied. Of particular interest are two large studies in the UK $[60,150]$. In most studies with children, parent and teachers have reported improvements; however cognitive assessments detected varied (mostly no) improvements. In the Durham trial [60], reading and spelling were included as outcome measures with highly significant, and meaningful, improvements in these literacy indicators. In the prison-based trial with criminal offenders [150], a 
range of psychological assessments were used that did not detect any response to micronutrient $/ \mathrm{n}-3$ PUFA supplementation; however prison disciplinary actions were recorded in the treatment and placebo groups and detected significantly less reprimands in the treatment group, particularly in violent behaviour. Therefore selection of outcome measures is an area in serious need of attention.

Finally, only one study appears to have conducted a follow-up; four months after treatment ceased, anger levels remained low [156]; whether this was due to retention of n-3 PUFA in cell membranes or a result of newly learned behavioral changes remains to be determined and also needs to be investigated by future researchers. In conclusion, as well as identifying likely responders, future research investigating effects of n-3 PUFA supplementation on mental health and behavior needs to define meaningful and long term outcomes and optimal supplementation strategies including combinations with other lifestyle risk factors and nutrients that are consumed suboptimally.

\section{Notes added in proof}

After writing this review another study was identified by a group in Israel (Raz et al., 2009). They published a randomised controlled trial with 7-13 year old unmedicated children with ADHD that reported no treatment effects on parent and teacher questionnaires or a computerised continuous performance task. However the PUFA supplement contained relatively small amounts of LA (480mg) and ALA (120mg), the latter of which is likely to have had minimal conversion to EPA and DHA, and they were only supplemented for 7 weeks, whereas at least 8 and preferably a minimum of 12 weeks tend to be required to show any improvements overall, and with larger doses of long-chain n-3 PUFAs. Interestingly they did report some improvements in both groups which could be a placebo effect although the placebo contained vitamin $\mathrm{C}$ and was therefore not a non-active compound.

Raz, R.; Carasso, R. L.; Yehuda, S. The Influence of Short-Chain Essential Fatty Acids on Children with Attention-Deficit/Hyperactivity Disorder: A Double-Blind Placebo-Controlled Study. J Child Adolesc Psychopharmaco, 2009, 19, 167-177.

\section{Acknowledgements}

NS holds an Australian Research Council (ARC)-Linkage Postdoctoral Fellowship; she and PH are recipients of an ARC-Linkage project grant (LP0776922) in partnership with Novasel Australia entitled "Cognitive and behavioural benefits of omega-3 fatty acids across the lifespan." CM is supported by a PhD scholarship from the South Australian Health Department.

\section{References and Notes}

1. World Health Organisation. Mental health: WHO urges more investments, services for mental health, 2008. Available online: http://www.who.int/mental_health/en/ (accessed on 5 January 2008).

2. World Health Organisation. Prevention of mental disorders: Effective interventions and policy options. Presented at World Health Organisation, Geneva, Switzerland, 2004. 
3. Bourre, J. M. Effects of nutrients (in food) on the structure and function of the nervous system: update on dietary requirements for brain, part 1: micronutrients. J. Nutr. Health Aging 2006, 10, 377-385.

4. Bourre, J. M. Effects of nutrients (in food) on the structure and function of the nervous system: update on dietary requirements for brain, part 2: macronutrients. J. Nutr. Health Aging 2006, 10, 386-399.

5. Gomez-Pinilla, F. Brain foods: the effects of nutrients on brain function. Nature 2008, 9, 568-578.

6. Nutritional Neuroscience; Lieberman, H.R., Kanarek, R.B., Prasad, C., Eds.; Taylor \& Francis Group: Boca Raton, FL, USA, 2005.

7. Crawford, M.A.; Sinclair, A.J. Nutritional influences in the evolution of mammalian brain. Presented at Lipids, Malnutrition and the Developing Brain, ASP (Elsevier; Excerpta Medica; North-Holland): Amsterdam, the Netherland, 1971.

8. Sinn, N.; Milte, C.; Howe, P.R.C. From ADHD to Alzheimer's: Omega-3 fatty acids and mental health. In Fatty Acids in Health Promotion and Disease; Watson, R., Ed.; AOCS press: Urbana, IL, USA, 2009.

9. World Health Organisation. International Clinical Trials Registry Platform, 2009. Available online: http://apps.who.int/trialsearch/ (accessed on 15, October 2009).

10. Simopoulos, A.P. Omega-3 fatty acids in health and disease and in growth and development. Am. J. Clin. Nutr. 1991, 54, 438-463.

11. Harris, W.S.; von Schacky, C. The Omega-3 Index: a new risk factor for death from coronary heart disease? Prev. Med. 2004, 39, 212-220.

12. Hamilton, J.; Greiner, R.; Salem, N., Jr.; Kim, H.-Y. n-3 fatty acid deficiency decreases phosphatidylserine accumulation selectively in neuronal tissues. Lipids 2000, 35, 863-869.

13. Horrocks, L.A.; Yeo, Y.K. Health benefits of docosahexaenoic acid (DHA). Pharmacol. Res. 1999, 40, 211-225.

14. Salem, N., Jr.; Litman, B.; Kim, H.-Y.; Gawrisch, K. Mechanisms of action of docosahexaenoic acid. Lipids 2001, 36, 945-959.

15. Salem, N.; Kim, H.-Y.; Yergey, J. A. Docosahexaenoic acid: membrane function and metabolism. In Health effects of polyunsaturated fatty acids in seafoods; Simopoulos, A.P., Kifer, R.R., Martin, R.E., Ed.; Academic Press: Orlando, FL, USA, 1986; pp. 263-317.

16. Bourre, J.-M.; Dumont, O. The administration of pig brain phospholipids versus soybean phospholipids in the diet during the period of brain development in the rat results in greater increments of brain docosahexaenoic acid. Neurosci. Lett. 2002, 335, 129-133.

17. Carrié, I.; Clément, M.; de Javel, D.; Francès, H.; Bourre, J.-M. Specific phospholipid fatty acid composition of brain regions in mice: effects of n-3 polyunsaturated fatty acid deficiency and phospholipid supplementation. J. Lipid Res. 2000, 41, 465-472.

18. Galli, C.; Trzeciak, H.I.; Paoletti, R. Effects of essential fatty acid deficiency on myelin and various subcellular structures in rat brain. J. Neurochem. 1972, 19, 1863-1867.

19. Yehuda, S.; Rabinovitz, S.; Carasso, R.L.; Mostofsky, D.I. Fatty acids and brain peptides. Peptides 1998, 19, 407-419. 
20. Yehuda, S.; Rabinovitz, S.; Carasso, R.L.; Mostofsky, D.I. The role of polyunsaturated fatty acids in restoring the aging neuronal membrane. Neurobiol. Aging 2002, 23, 843-853.

21. Tiemeier, H.; van Tuijl, H.R.; Hofman, A.; Kiliaan, A.J.; Breteler, M.M. Plasma fatty acid composition and depression are associated in the elderly: the Rotterdam Study. Am. J. Clin. Nutr. 2003, 78, 40-46.

22. Assisi, A.; Banzi, R.; Buoinocore, C.; Capasso, F.; Muzio, V.D.; Michelacci, F.; Renzo, D.; Tafuri, G.; Trotta, F.; Maria, V.; Garattini, S. Fish oil and mental health: the role of n-3 long-chain polyunsaturated fatty acids in cognitive development and neurological disorders. Int. Clin. Psychopharmacol. 2006, 21, 319-336.

23. Haag, M. Essential fatty acids and the brain. Can. J. Psychiatry 2003, 48, 195-203.

24. Young, G.; Conquer, J. Omega-3 fatty acids and neuropsychiatric disorders. Reprod. Nutr. Dev. 2005, 45, 1-28.

25. Leaf, A.; Kang, J.X. Omega-3 fatty acids and cardiovascular disease. In Nutrition and Fitness: Diet, Genes, Physical Activity and Health; Simopoulos, A.P., Pavlou, K.N., Ed.; Karger: Basel, Switzerland, 2001; pp. 161-172.

26. Horrobin, D.F. The membrane phospholipid hypothesis as a biochemical basis for the neurodevelopmental concept of schizophrenia. Schizophr. Res. 1998, 30, 193-208.

27. Youdim, K.A.; Martin, A.; Joseph, J.A. Essential fatty acids and the brain: possible health implications. Int. J. Dev. Neurosci. 2000, 18, 383-399.

28. Chalon, S. Omega-3 fatty acids and monoamine neurotransmission. Prostaglandins Leukot. Essent. Fatty Acids 2006, 75, 259-269.

29. Chalon, S.; Vancassel, S.; Zimmer, L.; Guilloteau, D.; Durand, G. Polyunsaturated fatty acids and cerebral function: Focus on monoaminergic neurotransmission. Lipids 2001, 36, 937-944.

30. Lauritzen, L.; Hansen, H. S.; Jørgensen, M. H.; Michaelsen, K. F. The essentiality of long chain n3 fatty acids in relation to development and function of the brain and retina. Prog. Lipid Res. 2001, 40, 1-94.

31. Hibbeln, J.R.; Linnoila, M.; Umhau, J.C.; Rawlings, R.; George, D.T.; Salem, N., Jr. Essential fatty acids predict metabolites of serotonin and dopamine in cerebrospinal fluid among healthy control subjects, and early- and late-onset al.coholics. Biol. Psychiatry 1998, 44, 235-242.

32. Froehlich, J. C. Opioid Peptides. Alcohol Health Res. World 1997, 21, 132-136.

33. Mori, T.A.; Watts, G.F.; Burke, V.; Hilme, E.; Puddey, I.B.; Beilin, L.J. Differential effects of eicosapentaenoic acid and docosahexaenoic acid on vascular reactivity of the forearm microcirculation in hyperlipidemic, overweight men. Circulation 2000, 102, 1264-1269.

34. da Silva, A.X.; Lavialle, F.; Gendrot, G.; Guesnet, P.; Alessandri, J.-M.; Lavialle, M. Glucose transport and utilization are altered in the brain of rats deficient in n-3 polyunsaturated fatty acids. J. Neurochem. 2002, 81, 1328-1337.

35. Pifferi, F.; Roux, F.; Langelier, B.; Alessandri, J.-M.; Vancassel, S.; Jouin, M.; Lavialle, M.; Guesnet, P. (n-3) polyunsaturated fatty acid deficiency reduces the expression of both isoforms of the brain glucose transporter GLUT1 in rats. J. Nutr. 2005, 135, 2241-2246.

36. Sinn, N.; Howe, P.R.C. Mental health benefits of omega-3 fatty acids may be mediated by improvements in cerebral vascular function. Biosci. Hypotheses 2008, 1, 103-108. 
37. Hooijmans, C.R.; Kiliaan, A.J. Fatty acids, lipid metabolism and Alzheimer pathology. Eur. J. Pharmacol. 2008, 585, 176-196.

38. Smithers, L.; Makrides, M. Effect of dietary long-chain polyunsaturated fatty acids in infancy on both visual and neural development. In Fatty Acids in Health Promotion and Disease Causation; Watson, R.R., Ed.; AOCS Press: Urbana, IL, USA, 2009; pp. 349-377.

39. Richardson, A.J. Omega-3 fatty acids in ADHD and related neurodevelopmental disorders. Int. Rev. Psychiatry 2006, 18, 155-172.

40. Sinn, N. Nutritional and dietary influences on attention deficit hyperactivity disorder. Nutr. Rev. 2008, 66, 558-568.

41. Sinclair, A.J.; Begg, D.; Mathai, M.; Weisinger, R.S. Omega 3 fatty acids and the brain: review of studies in depression. Asia Pac. J. Clin. Nutr. 2007, 16, 391-397.

42. Thatcher, R.W. Maturation of the human frontal lobes. Physiological evidence for staging. Dev. Neuropsychol. 1991, 7, 397-419.

43. Toga, A.W.; Thompson, P.M.; Sowell, E.R. Mapping brain maturation. Trends Neurosci. 2006, 29, 148-159.

44. Arnold, L.E.; Kleykamp, D.; Votolato, N.A.; Taylor, W.A.; Kontras, S.B.; Tobin, K. Gammalinolenic acid for attention-deficit hyperactivity disorder: placebo-controlled comparison to Damphetamine. Biol. Psychiatry 1989, 25, 222-228.

45. Burgess, J.R.; Stevens, L.J.; Zhang, W.; Peck, L. Long-chain polyunsaturated fatty acids in children with attention-deficit hyperactivity disorder. Am. J. Clin. Nutr. 2000, 71, 327-330.

46. Chen, J.-R.; Hsu, S.-F.; Hsu, C.-D.; Hwang, L.-H.; Yang, S.-C. Dietary patterns and blood fatty acid composition in children with attention-deficit hyperactivity disorder in Taiwan. J. Nutr. Biochem. 2004, 15, 467-472.

47. Colquhoun, I.; Bunday, S. A lack of essential fatty acids as a possible cause of hyperactivity in children. Med. Hypotheses 1981, 7, 673-679.

48. Mitchell, E.A.; Aman, M.G.; Turbott, S.H.; Manku, M. Clinical characteristics and serum essential fatty acid levels in hyperactive children. Clin. Pediatr. 1987, 26, 406-411.

49. Mitchell, E.A.; Lewis, S.; Cutler, D.R. Essential fatty acids and maladjusted behaviour in children. Prostaglandins Leukot Med. 1983, 12, 281-287.

50. Stevens, L.J.; Zentall, S.S.; Abate, M.L.; Kuczek, T.; Burgess, J.R. Omega-3 fatty acids in boys with behavior, learning, and health problems. Physiol. Behav. 1996, 59, 915-920.

51. Stevens, L.J.; Zentall, S.S.; Deck, J.L.; Abate, M.L.; Watkins, B.A.; Lipp, S.R.; Burgess, J.R. Essential fatty acid metabolism in boys with attention-deficit hyperactivity disorder. Am. J. Clin. Nutr. 1995, 62, 761-768.

52. Aman, M.G.; Mitchell, E.A.; Turbott, S.H. The effects of essential fatty acid supplementation by Efamol in hyperactive children. J. Abnorm. Child Psychol. 1987, 15, 75-90.

53. Voigt, R.G.; Llorente, A.M.; Jensen, C.L.; Fraley, J.K.; Berretta, M.C.; Heird, W.C. A randomised, double-blind, placebo-controlled trial of docosahexaenoic acid supplementation in children with attention-deficit/hyperactivity disorder. J. Pediatr. 2001, 139, 189-196. 
54. Richardson, A.J. Clinical trials of fatty acid supplementation in ADHD. In Phospholipid Spectrum Disorders in Psychiatry and Neurology; Glen, A.I.M., Peet, M., Horrobin, D.F., Eds.; Marius Press: Carnforth, UK, 2003; pp. 529-541.

55. Hirayama, S.; Hamazaki, T.; Terasawa, K. Effect of docosahexaenoic acid-containing food administration on symptoms of attention-deficit/hyperactivity disorder - a placebo-controlled double-blind study. Eur. J. Clin. Nutr. 2004, 58, 467-473.

56. Bourre, J.-M.; Durand, G.; Pascal, G.; Youyou, A. Brain cell and tissue recovery in rats made deficient in n-3 fatty acids by alteration of dietary fat. J. Nutr. 1989, 119, 15-22.

57. Moriguchi, T.; Loewke, J.; Garrison, M.; Catalan, J.N.; Salem, N., Jr. Reversal of docosahexaenoic acid deficiency in the rat brain, retina, liver, and serum. J. Lipid Res. 2001, 42, 419-427.

58. Richardson, A.J.; Puri, B.K. A randomised double-blind, placebo-controlled study of the effects of supplementation with highly unsaturated fatty acids on ADHD-related symptoms in children with specific learning difficulties. Prog. Neuro-Psychopharmacol. Biol. Psychiatry 2002, 26, 233-239.

59. Stevens, L.J.; Zhang, W.; Peck, L.; Kuczek, T.; Grevstad, N.; Mahon, A.K.; Zentall, S.S.; Arnold, L.E.; Burgess, J.R. EFA supplementation in children with inattention, hyperactivity, and other disruptive behaviors. Lipids 2003, 38, 1007-1021.

60. Richardson, A.J.; Montgomery, P. The Oxford-Durham study: a randomised, controlled trial of dietary supplementation with fatty acids in children with developmental coordination disorder. Pediatrics 2005, 115, 1360-1366.

61. Sinn, N.; Bryan, J. Effect of supplementation with polyunsaturated fatty acids and micronutrients on ADHD-related problems with attention and behavior. J. Dev. Behav. Pediatr. 2007, 28, 82-91.

62. Sinn, N.; Bryan, J.; Wilson, C. Cognitive effects of polyunsaturated fatty acids in children with attention deficit hyperactivity disorder symptoms: A randomised controlled trial. Prostaglandins Leukot. Essent. Fatty Acids 2008, 78, 311-326.

63. Sinn, N. Physical fatty acid deficiency signs in children with ADHD symptoms. Prostaglandins Leukot. Essent. Fatty Acids 2007, 77, 109-115.

64. Johnson, M.; Östlund, S.; Fransson, G.; Kadesjö, B.; Gillberg, C. Omega-3/omega-6 fatty acids for attention deficit hyperactivity disorder. J. Atten. Disord. 2008, 12, 394-401.

65. Milte, C.; Sinn, N.; Buckley, J.D.; Coates, A.M.; Young, R.M.; Howe, P.R.C. Erythrocyte polyunsaturated fatty acids, cognition and literacy in children with ADHD and learning difficulties. In preparation.

66. Sinn, N.; Milte, C.; Coates, A.M.; Buckley, J.D.; Young, R.M.; Howe, P.R.C. Childhood behaviour and learning disorders respond to changes in erythrocyte polyunsaturated fatty acid content. Presented at Nutrition Society of Australia, Newcastle, NSW, Australia, 2009.

67. Bell, J.G.; MacKinlay, E.E.; Dick, J.R.; MacDonald, D.J.; Boyle, R.M.; Glen, A.C.A. Essential fatty acids and phospholipase A2 in autistic spectrum disorders. Prostaglandins Leukot. Essent. Fatty Acids 2004, 71, 201-204.

68. Bell, J.G.; Sargent, J.R.; Tocher, D.R.; Dick, J.R. Red blood cell fatty acid compositions in a patient with autistic spectrum disorder: a characteristic abnormality in neurodevelopmental disorders? Prostaglandins Leukot. Essent. Fatty Acids 2000, 63, 21-25. 
69. Baker, S.M. A biochemical approach to the problem of dyslexia. J. Learn Disabil. 1985, 18, 581-584.

70. Richardson, A.J.; Cox, I.J.; Sargentoni, J.; Puri, B.K. Abnormal cerebral phospholipid metabolism in dyslexia indicated by phosphorus-31 magnetic resonance spectroscopy. NMR in Biomed. 1997, 10, 309-314.

71. Richardson, A.J.; Ross, M.A. Fatty acid metabolism in neurodevelopmental disorder: a new perspective on associations between attention-deficit/hyperactivity disorder, dyslexia, dyspraxia and the autistic spectrum. Prostaglandin Leukot. Essent. Fatty Acids 2000, 63, 1-9.

72. Stordy, B.J. Dark adaptation, motor skills, docosahexaenoic acid, and dyslexia. Am. J. Clin. Nutr. 2000, 71, 323-326.

73. Taylor, K.E.; Higgins, C.J.; Calvin, C.M.; Hall, J.A.; Easton, T.; McDaid, A.M.; Richardson, A.J. Dyslexia in adults is associated with clinical signs of fatty acid deficiency. Prostaglandins Leukot. Essent. Fatty Acids 2000, 63, 75-78.

74. Taylor, K.E.; Richardson, A.J. Visual function, fatty acids and dyslexia. Prostaglandins Leukot. Essent. Fatty Acids 2000, 63, 89-93.

75. Vancassel, S.; Durand, G.; Barthelemy, C. Plasma fatty acid levels in autistic children. Prostaglandins Leukot. Essent. Fatty Acids 2001, 65, 1-7.

76. Belluzi, A. n-3 fatty acids for the treatment of inflammatory bowel diseases. Proc. Nutr. Soc. 2002, 61, 391-395.

77. Horvath, K.; Perman, J.A. Autism and gastrointestinal symptoms. Curr. Gastroenterol. Rep. 2002, 4, 251-258.

78. Johnson, S.M.; Hollander, E. Evidence that eicosapentaenoic acid is effective in treating autism. $J$. Clin. Psychiatry 2003, 64, 848-849.

79. Patrick, L.; Salik, R. Benefits of essential fatty acid supplementation on language and learning skills in children with autism and Asperger's syndrome. Available online: www.nordicnaturals.com/images/pdfs/PatrickStudy05.pdf(accessed on 15 October 2009).

80. Amminger, G.P.; Berger, G.E.; Schäfer, M.R.; Klier, C.; Friedrich, M.H.; Feucht, M. Omega-3 fatty acids supplementation in children with autism: A double-blind randomized, placebocontrolled pilot study Biol. Psychiatry 2007, 61, 551-553.

81. Zimmerman, A.W.; Jinnah, H.A.; Lockhart, P.J. Behavioral Neuropharmacology. Ment. Retard Dev. Disabil. Res. Rev. 1998, 4, 26-35.

82. Miller, M.L.; Fee, V.E.; Netterville, A.K. Psychometric properties of ADHD rating scales among children with mental retardation I: Reliability. Res. Dev. Disabil. 2004, 25, 459-476.

83. Phelps, L.; Brown, R.T.; Power, T.J. Mental retardation and autistic spectrum disorders. In Pediatric psychopharmacology: Combining medical and psychosocial interventions; Phelps, L., Brown, R.T., Power, T.J., Eds.; American Psychological Association: Washington, DC, USA, 2002; pp. 133-161.

84. Chechlacz, M.; Gleeson, J.G. Is mental retardation a defect of synapse structure and function? Pediatr. Neurol. 2003, 29, 11-17. 
85. Sinn, N.; Wilson, C. Dietary supplementation with highly unsaturated fatty acids: Implications for interventions with persons with mental retardation from research on infant cognitive development, ADHD, and other developmental disabilities. Int. Rev. Res. Ment. Retard. 2006, 32, 159-196.

86. Hibbeln, J.R. Fish consumption and major depression. The Lancet 1998, 351, 1213.

87. Hibbeln, J.R.; Salem, N., Jr. Dietary polyunsaturated fatty acids and depression: When cholesterol does not satisfy. Am. Clin. Nutr. 1995, 62, 1-9.

88. Peet, M. International variations in the outcome of schizophrenia and the prevalence of depression in relation to national dietary practices: an ecological analysis. Br. J. Psychiatry 2004, 184, 404408.

89. Tanskanen, A.; Hibbeln, J. R.; Hintikka, J.; Haatainen, K. Fish consumption, depression, and suicidality in a general population / in reply. Arch. Gen. Psychiatry 2001, 58, 512.

90. Tanskanen, A.; Hibbeln, J. R.; Tuomilehto, J.; Uutela, A.; Haukkala, A.; Viinamaki, H.; Lehtonen, J.; Vartiainen, E. Fish consumption and depressive symptoms in the general population in Finland. Psychiatr. Serv. 2001, 52, 529-531.

91. Horrobin, D. F.; Bennett, C. N. Depression and bipolar disorder: relationships to impaired fatty acid and phospholipid metabolism and to diabetes, cardiovascular disease, immunological abnormalities, cancer, ageing and osteoporosis. Prostaglandins Leukot Essent Fatty Acids 1999, 60, 217-234.

92. Schins, A.; Crijns, H. J.; Brummer, R.-J. M.; Wichers, M.; Lousberg, R.; Celis, S.; Honig, A. Altered omega-3 polyunsaturated fatty acid status in depressed post-myocardial infarction patients. Acta Psychiatr. Scand. 2007, 115, 35-40.

93. Frasure-Smith, N.; Lespérance, F.; Julien, P. Major depression is associated with lower omega-3 fatty acid levels in patients with recent acute coronary syndromes. Biol. Psychiatry 2004, 55, 891-896.

94. Adams, P.B.; Lawson, S.; Sanigorski, A.; Sinclair, A.J. Arachidonic acid to eicosapentaenoic acid ratio in blood correlates positively with clinical symptoms of depression. Lipids 1996, 31, S157-161.

95. Assies, J.; Lok, A.; Bockting, C. L.; Weverling, G. J.; Lieverse, R.; Visser, I.; Abeling, N. G. G. M.; Duran, M.; Schene, A. H. Fatty acids and homocysteine levels in patients with recurrent depression: an explorative pilot study. Prostaglandins Leukot. Essent. Fatty Acids 2004, 70, 349-356.

96. De Vriese, S.R.; Christophe, A.B.; Maes, M. Lowered serum n-3 polyunsaturated fatty acid (PUFA) levels predict the occurrence of postpartum depression: Further evidence that lowered nPUFAs are related to major depression Life Sci. 2003, 73, 3181-3187.

97. Edwards, R.; Peet, M.; Shay, J.; Horrobin, D.F. Omega-3 polyunsaturated fatty acid levels in the diet and in red blood cell membranes of depressed patients. J. Affective Disord. 1998, 48, 149-155.

98. Maes, M.; Christophe, A.B.; Delanghe, J.; Altamura, C.; Neels, H.; Meltzer, H.Y. Lowered omega3 polyunsaturated fatty acids in serum phospholipids and cholesteryl esters of depressed patients. Psychiatry Res. 1999, 85, 275-291. 
99. Peet, M.; Murphy, B.; Shay, J.; Horrobin, D.F. Depletion of omega-3 fatty acid levels in red blood cell membranes of depressed patients. Biol. Psychiatry 1998, 43, 315-319.

100.McNamara, R.K.; Hahn, C.-G.; Jandacek, R.; Rider, T.; Tso, P.; Stanford, K.E.; Richtand, N.M. Selective deficits in the omega-3 fatty acid docosahexaenoic acid in the postmorten orbitofrontal cortex of patients with major depressive disorder. Biol. Psychiatry 2007, 62, 17-24.

101.Puri, B.K.; Counsell, S.J.; Hamilton, G.; Richardson, A.J.; Horrobin, D.F. Eicosapentaenoic acid in treatment-resistant depression associated with symptom remission, structural brain changes and reduced neuronal phospholipid turnover. Int. J. Clin. Pract. 2001, 55, 65-63.

102.Stahl, L.A.; Begg, D.P.; Weisinger, R.S.; Sinclair, A.J. The role of omega-3 fatty acids in mood disorders. Curr. Opin. Invest. Drugs 2008, 9, 57-64.

103.Peet, M.; Horrobin, D.F. A dose-ranging study of the effects of ethyl-eicosapentaenoate in patients with ongoing depression despite apparently adequate treatment with standard drugs. Arch. Gen. Psychiatry 2002, 59, 913-919.

104.Nemets, B.; Stahl, Z.; Belmaker, R.H. Addition of omega-3 fatty acid to maintenance medication treatment for recurrent unipolar depressive disorder. Am. J. Psychiatry 2002, 159, 477-479.

105.Nemets, H.; Nemets, B.; Apter, A.; Bracha, Z.; Belmaker, R. H. Omega-3 treatment of childhood depression: A controlled, double blind pilot study. Am. J. Psychiatry 2006, 163, 1098-1100.

106.Su, K.-P.; Huang, S.-Y.; Chiu, C.-C.; Shen, W. W. Omega-3 fatty acids in major depressive disorder: A preliminary double-blind, placebo-controlled trial. Eur. Neuropsychopharmacol. 2003, 13, 267-271.

107.Jazayeri, S.; Tehrani-Doost, M.; Keshavarz, S.A.; Hosseini, M.; Djazayery, A.; Amini, H.; Jalali, M.; Peet, M. Comparison of therapeutic effects of omega-3 fatty acid eicosapentaenoic acid and fluoxetine, separately and in combination, in major depressive disorder. Aust. NZ J. Psychiatry 2008, 42, 192-198.

108.Lucas, M.; Asselin, G.; Mérette, C.; Poulin, M. J.; Dodin, S. Ethyl-eicosapentaenoic acid for the treatment of psychological distress and depressive symptoms in middle-aged women: a doubleblind, placebo-controlled, randomized clinical trial. Am. J. Clin. Nutr. 2009, 89, 641-651.

109.Su, K.-P.; Huang, S.-Y.; Chiu, T.-H.; Huang, K.-C.; Huang, C.-L.; Chang, H.-C.; Pariante, C. M. Omega-3 fatty acids for major depressive disorder during pregnancy: Results from a randomised, double-blind, placebo-controlled trial. J. Clin. Psychiatry 2008, 69, 644-651.

110.Freeman, M.P.; Hibbeln, J.; Wisner, K.; Brumbach, B.H.; Watchman, M.; Gelenberg, A.J. Randomized dose-ranging pilot trial of omega-3 fatty acids for postpartum depression. Acta Psychiatr. Scand. 2006, 113, 31-35.

111.Marangell, L.B.; Martinez, J.M.; Zboyan, H.A.; Kertz, B.; Seung Kim, H.F.; Puryear, L.J. A double-blind, placebo-controlled study of the omega-3 fatty acid docosahexaenoic acic in the treatment of major depression. Am. J. Psychiatry 2003, 160, 996-998.

112.Silvers, K.M.; Woolley, C.C.; Hamilton, F.C.; Watts, P.M.; Watson, R.A. Randomised doubleblind placebo-controlled trial of fish oil in the treatment of depression. Prostaglandins Leukot. Essent. Fatty Acids 2005, 72, 211-218. 
113.Grenyer, B.F.S.; Crowe, T.; Meyer, B.; Owen, A.J.; Grigonis-Deane, E.M.; Caputi, P.; Howe, P.R.C. Fish oil supplementation in the treatment of major depression: A randomised double-blind placebo-controlled trial. Prog. Neuropsychopharmacol. Biol. Psychiatry 2007, 31, 1393-1396.

114.Meyer, B.; Grenyer, B.F.S.; Crowe, T.; Owen, A.J.; Howe, P.R.C. Improvement of major depression is associated with increased erythrocyte DHA - subset analysis in a double-blind omega-3 supplementation trial. Presented at International Society for the Study of Fatty Acids and Lipids (ISSFAL), Brighton, UK 2004.

115.Freund-Levi, Y.; Basun, H.; Cederholm, T.; Faxén-Irving, G.; Garlind, A.; Grut, M.; Vedin, I.; Palmblad, J.; Wahlund, L.-O.; Eriksdotter-Jönhagen, M. Omega-3 supplementation in mild to moderate Alzheimer's disease: effects on neuropsychiatric symptoms. Int. J. Geriatr. Psychiatry 2008, 23, 161-169.

116.Carney, R.M.; Freedland, K.E.; Rubin, E.H.; Rich, M.W.; Steinmeyer, B.C.; Harris, W.S. Omega3 augmentation of sertraline in treatment of depression in patients with coronary heart disease: A randomized controlled trial. JAMA 2009, 302, 1651-1657.

117.Rogers, P.J.; Appleton, K.M.; Kessler, D.; Peters, T.J.; Gunnell, D.; Hayward, R.C.; Heatherley, S.V.; Christian, L.M.; McNaughton, S.A.; Ness, A.R. No effect of n-3 long-chain polyunsaturated fatty acid (EPA and DHA) supplementation on depressed mood and cognitive function: a randomised controlled trial. Br. J. Nutr. 2008, 99, 421-431.

118.van de Rest, O.; Geleijnse, J.M.; Kok, F.J.; van Staveren, W.A.; Hoefnagels, W.H.; Beekman, A.T.; de Groot, L.C. Effect of fish-oil supplementation on mental well-being in older subjects: A randomized, double-blind, placebo-controlled trial. Am. J. Clin. Nutr. 2008, 88, 706-713.

119.McNamara, R.K.; Jandacek, R.; Rider, T.; Tso, P.; Stanford, K.E.; Hahn, C.-G.; Richtand, N.M. Deficits in docosahexaenoic acid and associated elevations in the metabolism of arachidonic acid and saturated fatty acids in the postmortem orbitofrontal cortex of patients with bipolar disorder. Psychiatry Res. 2008, 160, 285-299.

120.Stoll, A.L.; Severus, W.E.; Freeman, M.P.; Rueter, S.; Zboyan, H.A.; Diamond, E.; Cress, K.K.; Marangell, L.B. Omega 3 fatty acids in bipolar disorder. Arch. Gen. Psychiatry 1999, 56, 407-412.

121.Osher, Y.; Bersudsky, Y.; Belmaker, R.H. Omega-3 eicosapentaenoic acid in bipolar depression: Report of a small open-label study. J. Clin. Psychiatry 2005, 66, 726-729.

122.Frangou, S.; Lewis, M.; McCrone, P. Efficacy of ethyl-eicosapentaenoic acid in bipolar depression: randomised double-blind placebo-controlled study. Br. J. Psychiatry 2006, 188, 46-50.

123.Keck, P.E.; Mintz, J.; McElroy, S.L.; Freeman, M.P.; Suppes, T.; Frye, M.A.; Altshuler, L.L.; Kupka, R.; Nolen, W.A.; Leverich, G.S.; Denicoff, K.D.; Grunze, H.; Duan, N.; Post, R.M. Double-blind, randomized, placebo-controlled trials of ethyl-eicosapentanoate in the treatment of bipolar depression and rapid cycling bipolar disorder. Biol. Psychiatry 2006, 60, 1020-1022.

124.Frangou, S.; Lewis, M.; Wollard, J.; Simmons, A. Preliminary in vivo evidence of increased Nacetyl-aspartate following eicosapentaenoic acid treatment in patients with bipolar disorder. $J$. Psychopharmacol. 2007, 21, 435-439. 
125.Hirashima, F.; Parow, A.M.; Stoll, A.L.; Demopulos, C.M.; Damico, K.E.; Rohan, M.L.; Eskesen, J.G.; Zuo, C.S.; Cohen, B.M.; Renshaw, P.F. Omega-3 fatty acid treatment and T(2) whole brain relaxation times in bipolar disorder. Am. J. Psychiatry 2004, 161, 1922-1924.

126.Brunner, J.; Parhofer, K.G.; Schwandt, P.; Bronisch, T. Cholesterol, essential fatty acids, and suicide. Pharmacopsychiatry 2002, 35, 1-5.

127.Hallahan, B.; Hibbeln, J.R.; Davis, J.M.; Garland, M.R. Omega-3 fatty acid supplementation in patients with recurrent self-harm. Single-centre double-blind randomised controlled trial. $\mathrm{Br}$. $J$. Psychiatry 2007, 190, 118-122.

128.Fenton, W.S.; Hibbeln, J.R.; Knable, M. Essential fatty acids, lipid membrane abnormalities, and the diagnosis and treatment of schizophrenia. Biol. Psychiatry 2000, 47, 8-21.

129.Horrobin, D.F. Schizophrenia and membrane lipids. In Lipids, health, and behavior; Hillbrand, M., Spitz, R.T., Eds.; American Psychological Association: Washington DC, USA, 1997; pp. 179-194.

130.Peet, M. Eicosapentaenoic acid in the treatment of schizophrenia and depression: rationale and preliminary double-blind clinical results. Prostaglandins Leukot. Essent. Fatty Acids 2003, 69, 477-485.

131.Puri, B.K.; Richardson, A.J. Sustained remission of positive and negative symptoms of schizphrenia following treatment with eicosapentaenoic acid. Arch. Gen. Psychiatry 1998, 55, 188-189.

132.Arvindakshan, M.; Ghate, M.; Ranjekar, P.; Evans, D.R.; Mahadik, S.P. Supplementation with a combination of w-3 fatty acids and antioxidants (vitamins E and C) improves the outcome of schizophrenia. Schizophrenia Res. 2003, 62, 195-204.

133.Assies, J.; Lieverse, R.; Vreken, P.; Wanders, R.J.A.; Dingemans, P.M.J.A.; Linszen, D.H. Significantly reduced docosahexaenoic and docosapentaenoic acid concentrations in erythrocyte membranes from schizophrenic patients compared with a carefully matched control group. Biol. Psychiatry 2001, 49, 510-522.

134.Kale, A.; Joshi, S.; Naphade, N.; Sapkale, S.; Raju, M.S.V.K.; Pillai, A.; Nasrallah, H.; Mahadik, S.P. Opposite changes in predominantly docosahexaenoic acid (DHA) in cerebrospinal fluid and red blood cells from never-medicated first-episode psychotic patients. Schizophrenia Res. 2008, 98, 295-301.

135.Peet, M.; Laugharne, J.D.E.; Mellor, J.; Ramchand, C.N. Essential fatty acid deficiency in erythrocyte membranes from chronic schizophrenic patients, and the clinical effects of dietary supplementation. Prostaglandins Leukot. Essent. Fatty Acids 1996, 55, 71-75.

136.Richardson, A.J.; Cyhlarova, E.; Ross, M.A. Omega-3 and omega-6 fatty acid concentrations in red blood cell membranes relate to schizotypal traits in healthy adults. Prostaglandins Leukot Essent Fatty Acids 2003, 69, 461-466.

137.Laugharne, J.D.E.; Mellor, J.E.; Peet, M. Fatty acids and schizophrenia. Lipids 1996, 31, S163-S165.

138.Emsley, R.; Myburgh, C.; Oosthuizen, P.; van Rensburg, S.J. Randomized, placebo-controlled study of ethyl-eicosapentaenoic acid as supplemental treatment in schizophrenia. Am. J. Psychiatry 2002, 159, 1596-1598. 
139.Peet, M.; Brind, J.; Ramchand, C.N.; Shah, S.; Vankar, G.K. Two double-blind placebo-controlled pilot studies of eicosapentaenoic acid in the treatment of schizophrenia. Schizophr. Res. 2001, 49, 243-251.

140.Peet, M.; Horrobin, D.F. A dose-ranging exploratory study of the effects of ethyleicosapentaenoate in patients with persistent schizophrenic symptoms. J. Psychiatr. Res. 2002, 36, $7-18$.

141.Fenton, W.S.; Dickerson, F.; Boronow, J.; Hibbeln, J.R.; Knable, M. A placebo-controlled trial of omega-3 fatty acid (ethyl eicosapentaenoic acid) supplementation for residual symptoms and cognitive impairment in schizophrenia. Am. J. Psychiatry 2001, 158, 2071-2074.

142.Horrobin, D.F. Omega-3 fatty acid for schizophrenia. A. J. Psychiatry 2003, 160, 188-189.

143.Hibbeln, J.R.; Makino, K.K.; Martin, C.E.; Dickerson, F.; Boronow, J.; Fenton, W.S. Smoking, gender, and dietary influences on erythrocyte essential fatty acid composition among patients with schizophrenia or schizoaffective disorder. Biol. Psychiatry 2003, 53, 431-441.

144.Berger, G.E.; Proffitt, T.-M.; McConchie, M.; Yuen, H.P.; Wood, S.J.; Amminger, P.; Brewer, W.; McGorry, P.D. Ethyl-eicosapentaenoic acid in first-episode psychosis: A randomised, placebo-controlled trial. J. Clin. Psychiatry 2007, 68, 1867-1875.

145.Amminger, P.G.; Schäfer, M.R.; Papageorgiou, K.; Klier, C.M.; Cotton, S.M.; Harrigan, S.M.; Mackinnon, A.; McGorry, P.D.; Berger, G.E. Long-chain $\omega-3$ fatty acids for indicated prevention of psychotic disorders. Arch. Gen. Psychiatry 2010, 67, 146-154.

146. Hallahan, B.; Garland, M.R. Essential fatty acids and their role in the treatment of impulsivity disorders. Prostaglandins Leukot. Essent. Fatty Acids 2004, 71, 211-216.

147.Hamazaki, T.; Sawazaki, S.; Itomura, M.; Asaoka, E.; Nagao, Y.; Nishimura, N.; Yazawa, K.; Kuwamori, T.; Kobayashi, M. The effect of docosahexaenoic acid on aggression in young adults: a placebo controlled double-blind study. J. Clin. Invest. 1996, 97, 1129-1134.

148.Bradbury, J.; Myers, S.P.; Oliver, C. An adaptogenic role for omega-3 fatty acids in stress; a randomised placebo controlled double blind intervention study (pilot). Nutr. J. 2004, 28, 20.

149.Zanarini, M.C.; Frankenburg, F.R. Omega-3 fatty acid treatment of women with borderline personality disorder: a double-blind, placebo-controlled pilot study. Am. J. Psychiatry 2003, 160, 167-169.

150.Gesch, C.B.; Hammond, S.M.; Hampson, S.E.; Eves, A.; Crowder, M.J. Influence of supplementary vitamins, minerals and essential fatty acids on the antisocial behaviour of young adult prisoners. Br. J. Psychiatry 2002, 181, 22-28.

151.Colledge, E.; Blair, R.J.R. The relationship in children between the inattention and impulsivity components of attention deficit and hyperactivity disorder and psychopathic tendencies. Pers. Individ. Diff. 2001, 30, 1175-1187.

152.Crowley, T.J.; Mikulich, S.K.; MacDonald, M.; Young, S.E.; Zerbe, G.O. Substance-dependent, conduct-disordered adolescent males: severity of diagnosis predicts 2-year outcome. Drug Alcohol Depend. 1998, 49, 225-237.

153.Root, R.W.I.; Resnick, R.J. An update on the diagnosis and treatment of attentiondeficit/hyperactivity disorder in children. Prof. Psychol. Res. Pract. 2003, 34, 34-41. 
154.Biederman, J.; Faraone, S.; Mick, E.; Wozniak, J.; Chen, L.; Ouellette, C.; Marrs, A.; Moore, P.; Garcia, J.; Mennin, D.; Lelon, E. Attention-deficit hyperactivity disorder and juvenile mania: an overlooked comorbidity? J. Am. Acad. Child Adolesc. Psychiatry 1996, 35, 997-1008.

155.Ingram, S.; Hechtman, L.; Morgenstern, G. Outcome issues in ADHD: Adolescent and adult longterm outcome. Ment. Retard. Dev. Disabil. 1999, 5, 243-250.

156.Buydens-Branchey, L.; Branchey, M. Long-chain n-3 polyunsaturated fatty acids decrease feelings of anger in substance abusers. Psychiatry Res. 2008, 157, 95-104.

157.Söderberg, M.; Edlund, C.; Kristensson, K.; Dallner, G. Fatty acid composition of brain phospholipids in aging and in Alzheimer's Disease. Lipids 1991, 26, 421-425.

158.Barberger-Gateau, P.; Raffaitin, C.; Letenneur, L.; Berr, C.; Tzourio, C.; Dartigues, J.F.; Alpérovitch, A. Dietary patterns and risk of dementia: the three-city cohort study. Neurology 2007, 69, 1921-1930.

159.Dullemeijer, C.; Durga, J.; Brouwer, I. A.; van de Rest, O.; Kok, F.J.; Brummer, R.-J.M.; van Boxtel, M.P.J.; Verhoef, P. n-3 Fatty acid proportions in plasma and cognitive performance in older adults. Am. J. Clin. Nutr. 2007, 86, 1479-1495.

160.Engelhart, M.J.; Geerlings, M.I.; Ruitenberg, A.; van Swieten, J.C.; Hofman, A.; Witteman, J.C.M.; Breteler, M.M.B. Diet and risk of dementia: Does fat matter? Neurology 2002, 59, 1915 1921.

161.Issa, A.M.; Mojica, W.A.; Morton, S.C.; Traina, S.; Newberry, S.J.; Hilton, L.G.; Garland, R.H.; MacLean, C.H. The efficacy of omega-3 fatty acids on cognitive function in aging and dementia: A systematic review. Dement Geriatr. Cogn. Disord. 2006, 21, 88-96.

162.Kalmijn, S. Fatty acid intake and the risk of dementia and cognitive decline: a review of clinical and epidemiological studies. J. Nutr. Health Aging 2000, 4, 202-207.

163.Kalmijn, S.; Launer, L.J.; Ott, A.; Witteman, J.C.M.; Hofman, A.; Breteler, M.M.B. Dietary fat intake and the risk of incident dementia in the Rotterdam study. Ann. Neurol. 1997, 42, 776-782.

164.Morris, M.C.; Evans, D.A.; Bienias, J.L.; Tangney, C.C.; Bennett, D.A.; Wilson, R.S.; Aggarwal, N.; Schneider, J. Consumption of fish and n-3 fatty acids and risk of incident Alzheimer Disease. Arch. Neurol. 2003, 60, 940-946.

165.Nurk, E.; Drevon, C.A.; Refsum, H.; Solvoll, K.; Vollset, S.E.; Nygård, O.; Nygaard, H.A.; Engedal, K.; Tell, G.S.; Smith, A.D. Cognitive performance among the elderly and dietary fish intake: the Hordaland Health Study. Am. J. Clin. Nutr. 2007, 86, 1470-1478.

166.Peers, R.J. Alzheimer's disease and omega-3 fatty acids: hypothesis. Med. J. Aust. 1990, 153, 563-564.

167.Tully, A.M.; Roche, H.M.; Doyle, R.; Fallon, C.; Bruce, I.; Lawlor, B.; Coakley, D.; Gibney, M.J. Low serum cholesteryl ester-docosahexaenoic acid levels in Alzheimer's disease: a case-control study. Br. J. Nutr. 2003, 89, 483-489.

168. Yehuda, S.; Rabinovitz, S.; Carasso, R.L.; Mostofsky, D.I. Essential fatty acids preparation (SR-3) improves Alzheimer's patients quality of life. Int. J. Neurosci. 1996, 87, 141-149.

169.Terano, T.; Fujishiro, S.; Ban, T.; Yamamoto, K.; Tanaka, T.; Noguchi, Y.; Tamura, Y.; Yazawa, K.; Hirayama, T. Docosahexaenoic acid supplementation improves the moderately severe dementia from thrombotic cerebrovascular diseases. Lipids 1999, 34, S345-S346. 
170.Boston, P.F.; Bennett, A.; Horrobin, D.F.; Bennett, C.N. Ethyl-EPA in Alzheimer's disease - a pilot study. Prostaglandins Leukot. Essent. Fatty Acids 2004, 71, 341-346.

171.Kotani, S.; Sakaguchi, E.; Warashina, S.; Matsukawa, N.; Ishikura, Y.; Kiso, Y.; Sakakibara, M.; Yoshimoto, T.; Guo, J.; Yamashima, T. Dietary supplementation of arachidonic and docosahexaenoic acids improves cognitive dysfunction. Neurosci. Res. 2006, 56, 159-164.

172.Freund-Levi, Y.; Eriksdotter-Jönhagen, M.; Cederholm, T.; Basun, H.; Faxen-Irving, G.; Garlind, A.; Vedin, I.; Vessby, B.; Wahlund, L.-O.; Palmblad, J. w-3 fatty acid treatment in 174 patients with mild to moderate Alzheimer Disease: OmegAD study. Arch. Neurol. 2006, 63, 1402-1408.

173.Chiu, C.-C.; Su, K.-P.; Cheng, T.-C.; Liu, H.-C.; Chang, C.-J.; Dewey, M. E.; Stewart, R.; Huang, S.-Y. The effects of omega-3 fatty acids monotherapy in Alzheimer's disease and mild cognitive impairment: A preliminary randomized double-blind placebo-controlled study. Prog. Neuropsychopharmacol. Biol. Psychiatry 2008, doi: 10.1016/j.pnpbp.2008.05.015.

174.van de Rest, O.; Geleijnse, J.M.; Kok, F.J.; van Staveren, W.A.; Dullemeijer, C.; Olderikkert, M.G.; Beekman, A.T.; de Groot, C.P. Effect of fish oil on cognitive performance in older subjects: A randomized, controlled trial. Neurology 2008, 71, 430-438.

175.Gauthier, S.; Reisberg, B.; Zaudig, M.; Peterson, R.; Ritchie, K.; Broich, K.; Belleville, S.; Brodaty, H.; Bennett, D.; Chertkow, H.; Cummings, J.L.; de Leon, M.; Feldman, H.; Ganguli, M.; Hampel, H.; Scheltens, P.; Tierney, M.C.; Whitehouse, P.; Winblad, B. Mild cognitive impairment. Lancet 2006, 367, 1262-1270.

176.Gabryelewicz, T.; Styczynska, M.; Pfeffer, A.; Wasiak, B.; Barczak, A.; Luczywek, E.; Androsiuk, W.; Barcikowska, M. Prevalence of major and minor depression in elderly persons with mild cognitive impairment - MADRS factor analysis. Int. J. Geriatr. Psychiatry 2004, 19, 1168-1172.

177.Modrego, P.; Ferrández, J. Depression in patients with mild cognitive impairment increases the risk of developing dementia of Alzheimer type. Arch. Neurol. 2004, 61, 1290-1293.

178.Peet, M. Nutrition and schizophrenia: beyond omega-3 fatty acids. Prostaglandins Leukot Essent Fatty Acids 2004, 70, 417-422.

179.Dangour, A.D.; Clemens, F.; Elbourne, D.; Fasey, N.; Fletcher, A.; Hardy, P.; Holder, G.E.; Huppert, F.A.; Knight, R.; Letley, L.; Richards, M.; Truesdale, A.; Vickers, M.; Uauy, R. A randomised controlled trial investigating the effect of n-3 long-chain polyunsaturated fatty acid supplementation on cognitive and retinal function in cognitively healthy older people: the Older People And n-3 Long-chain polyunsaturated fatty acids (OPAL) study protocol. Nutr. J. 2006, 31, 20.

180.Guyonnet-Gillette, S.; Andrieu, S.; Dantoine, T.; Dartigues, J.-F.; Touchon, J.; MAPT Study Group. Commentary on "A roadmap for the prevention of dementia II. Leon Thal Symposium 2008." The Multidomain Alzheimer Preventive Trial (MAPT): A new approach to the prevention of Alzheimer's disease. Alzheimers Dement 2009, 5, 114-121.

(C) 2010 by the authors; licensee Molecular Diversity Preservation International, Basel, Switzerland. This article is an open-access article distributed under the terms and conditions of the Creative Commons Attribution license (http://creativecommons.org/licenses/by/3.0/). 